\title{
27. GEOCHEMICAL DATA ON VOLCANIC ROCKS AND GLASSES RECOVERED FROM SITE 862: IMPLICATIONS FOR THE ORIGIN OF THE TAITAO RIDGE, CHILE TRIPLE JUNCTION REGION ${ }^{1}$
}

\author{
Randall D. Forsythe, ${ }^{2}$ James K. Meen, ${ }^{3}$ John F. Bender, ${ }^{2}$ and Don Elthon ${ }^{3}$
}

\begin{abstract}
Geochemical data for volcanic samples recovered at Site 862 of Leg 141 of the Ocean Drilling Program show that a wide diversity of magma types were generated in the region of the Taitao Ridge. We have divided the data into seven groups. Numerous samples belong to three groups of basaltic glasses-our Groups 1,2, and 5. Relative few samples of Groups 3, 4, and 6 were collected. Group 7 includes silicic samples that range from andesites to rhyolites.

Group 1 samples conform in most aspects of their major and trace element and isotopic chemistry and in their liquid line of descent to N-type mid-ocean ridge basalts (MORB) saturated in olivine and plagioclase. Group 2 samples differ from those of Group 1 in several features of their chemistry. They have higher contents of $\mathrm{K}_{2} \mathrm{O}$ and incompatible trace elements and are mildly light rare earth element (LREE)-enriched. Their $\mathrm{Nb}$ depletions and low values of $\mathrm{Ce} / \mathrm{Pb}$ and $\mathrm{K} / \mathrm{Pb}$ are consistent with addition of a subducted sediment-like component. $\mathrm{Sr}-\mathrm{Nd}$ and $\mathrm{Pb}$ isotopic compositions also indicate the presence of a component with higher time-integrated $\mathrm{Rb} / \mathrm{Sr}, \mathrm{U} / \mathrm{Pb}$, and $\mathrm{Th} / \mathrm{U}$ and lower $\mathrm{Sm} / \mathrm{Nd}$ than typical for the sources of MORBs. In addition, the Group 2 glasses define a trend of very limited Fe-enrichment, as for calc-alkaline rather than tholeiitic suites. Group 5 glasses have compositions intermediate between those of Group 1 and Group 2 glasses and suggest that there was a broad continuum of primary magmas depending upon the amount of sediment introduced into the mantle.

Group 1 glasses with $\mathrm{MgO}=8.0 \%$ fall on the global array of Klein and Langmuir (1987) between $\mathrm{Na}_{8.0}$ and $\mathrm{Fe}_{8.0}$, but lie off the arrays of $\mathrm{Na}_{8.0}$ and $\mathrm{Fe}_{8.0}$ against axial depth. If the glasses originally did conform to these arrays, the Taitao Ridge has been uplifted $2000-4000 \mathrm{~m}$.

The glassy plagioclase-hornblende-phyric rhyolites are plausibly melts of metamafic sources. Trace-element patterns and $\mathrm{Pb}$ isotopic compositions indicate that this source was chemically similar to Group 2 rocks. The higher ${ }^{87} \mathrm{Sr} /{ }^{86} \mathrm{Sr}$ of the rhyolites probably results from incorporation of seawater-derived fluids in these sources. Incompatible-element enrichments and REE patterns of the rhyolites are consistent with $10 \%$ melting of a Group 2 -like source to leave a residue of plagioclase and hornblende. In this case, phenocrysts in the rhyolites are probably restite.
\end{abstract}

\section{INTRODUCTION}

This study presents additional geochemical data and interpretations for a suite of volcanic samples that were recovered at Site 862 of Leg 141 of the Ocean Drilling Program (ODP). The site is located on the Taitao Ridge, a topographically anomalous feature along the Pacific continental margin of South America within the region of the Chile Triple Junction. An initial set of 17 rock samples was analyzed onboard the ship for whole rock compositions using X-ray fluorescence techniques (Behrmann, Lewis, Musgrave, et al., 1992). This study also includes microprobe data for glass shards and glassy basalt rinds; additional major- and trace-element data for some of the volcanic units not analyzed on board the ship, and isotopic analyses ( $\mathrm{Sr}$, $\mathrm{Nd}$, and $\mathrm{Pb}$ ) for a suite of representative samples.

The Taitao Ridge is a bathymetric promontory that extends southwestward into the Pacific Ocean from the continental margin of South America. The ridge extends approximately $15 \mathrm{~km}$ offshore, essentially along the azimuth of the Taitao Fracture Zone. Marine geophysical data discussed by Behrmann, Lewis, Musgrave, et al. (1992) point out several important characteristics of the ridge. First, despite its anomalous relief along the continental slope, multichannel seismic lines failed to image a clear deformation front along its boundaries with either the Antarctic or Nazca plates to the south and north, respectively. Second, the seismic data showed few, if any, coherent internal reflections, and an internal high seismic velocity. Third, the magnetic data obtained from a series of east-west profiles show two strongly lineated north-northwest-trending anomalies; and fourth, the

\footnotetext{
${ }^{1}$ Lewis, S.D., Behrmann, J.H., Musgrave, R.J., and Cande, S.C. (Eds.), 1995. Proc ODP, Sci. Results, 141: College Station, TX (Ocean Drilling Program).

2 Department of Geography and Earth Sciences, University of North Carolina at Charlotte, Charlotte, NC 28223, U.S.A.

${ }^{3}$ Department of Chemistry, University of Houston, Houston, TX 77204-5641. U.S.A
}

free-air gravity data included anomalies with amplitudes up to 200 mgal). The seismic, magnetic, and gravity data suggest that the Taitao Ridge consists of dense igneous lithologies formed by seafloor spreading processes. Because of the unknown nature of the boundaries of the Taitao Ridge with the surrounding oceanic floor, it is not currently known whether the ridge is part of the South American, Nazca, or Antarctic plates.

Southeast of the Taitao Ridge, a large ophiolite complex has been mapped on the Taitao Peninsula (Forsythe et al., 1986). This uplifted complex and some associated "near-trench plutons" (Kaeding et al., 1990) are dated by K/Ar methods and microfossils as late Miocene to Pliocene in age (Mpodozis et al., 1985; Forsythe et al., 1985). The age and location of the onshore igneous rocks have tied their formation and uplifting to the late Cenozoic arrival and subduction of the Chile Rise Spreading Center along the Peru-Chile Trench. The offshore Taitao Ridge, because of its proximity to the ophiolite and its geophysical characteristics, may represent an offshore extension of the Taitao ophiolite (see discussion by Behrmann, Lewis, Musgrave, et al., 1992). If true, then samples recovered from the ridge might provide further constraints on the origin of the ophiolite.

\section{TECTONOSTRATIGRAPHIC SETTING OF THE SITE 862 SAMPLE SUITE}

Three holes (862A, 862B, and $862 \mathrm{C}$ ) were drilled at Site 862 of ODP Leg 141 on the crest of the Taitao Ridge at a depth of approximately $1200-1300 \mathrm{~m}$ (Fig. 1). The relative positions and penetration depths of the three holes are illustrated in Figure 2. The lithologies of the recovered core show that the Taitao Ridge at this location is characterized by a 20 -m-thick sedimentary layer overlying volcanic rocks (Fig. 3). The upper sedimentary section was cored continuously at Hole $862 \mathrm{~A}$, but portions of this sedimentary cover also were recovered at Holes $862 \mathrm{~B}$ and $862 \mathrm{C}$. The underlying volcanic units were 


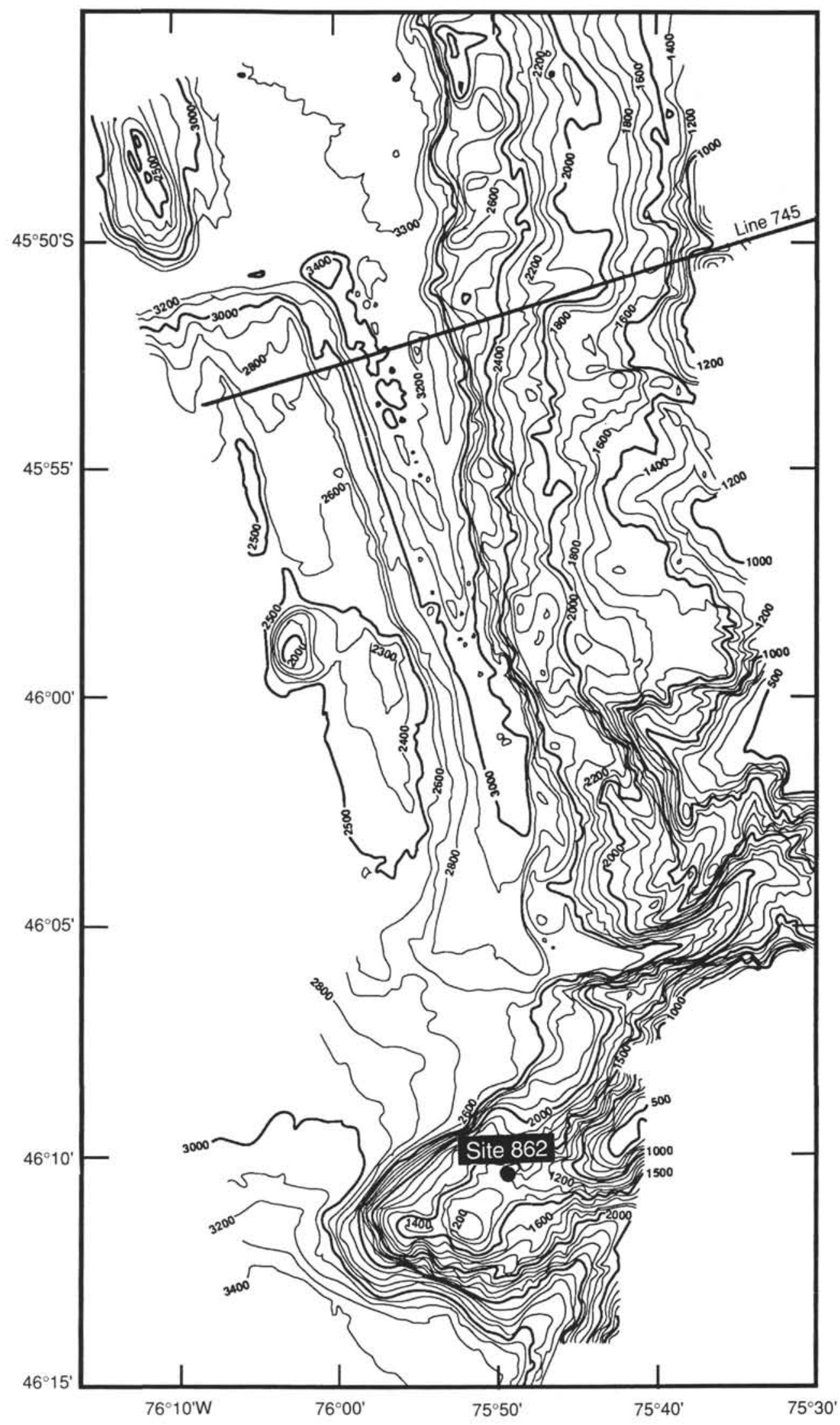

Figure 1. Location of the Taitao Ridge and Site 862. Bathymetry is derived from sonar profiling; contour interval is $100 \mathrm{~m}$. From Behrmann, Lewis, Musgrave, et al., 1992. 


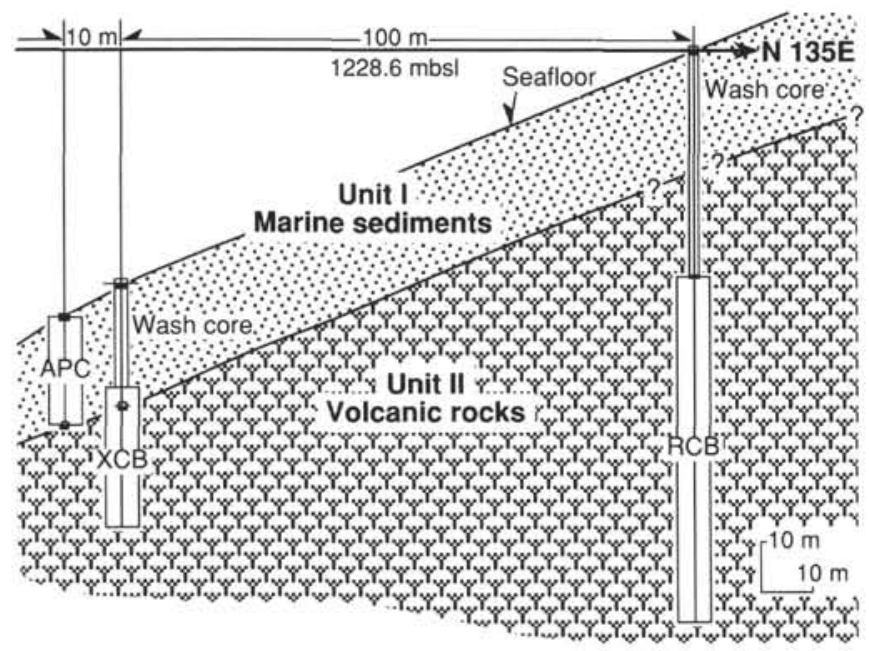

Figure 2. Topographic profile along the line of hole offsets on the Taitao Ridge at Site 862 , illustrating the depth, core recovery intervals, and the relative positions of the three holes. Hole $862 \mathrm{~A}$ is to the northwest; Hole $862 \mathrm{C}$ to the southeast. From Behrmann, Lewis, Musgrave, et al., 1992.

penetrated approximately $20 \mathrm{~m}$ at Hole $862 \mathrm{~B}$ and between 60 and 80 $\mathrm{m}$ at Hole $862 \mathrm{C}$.

The overlying sediments and sedimentary rocks are dominantly composed of silty clay to clayey silt and silty fine sand. The sediments are lithified within $6 \mathrm{~m}$ of the seafloor, suggesting that unroofing may have occurred. Microfossils (foraminifers and nannofossils) recovered from the sediments indicate an age of late Pliocene. In two of the holes, the recovered cores contained sedimentary rock in depositional contact with the glassy rinds of phyric basalt flows. Within the sedimentary units above and in contact with the volcanic rocks, abundant copper sulfides of a hydrothermal origin are found (Behrmann, Lewis, Musgrave, et al., 1992).

Volcanogenic material within the cores can be divided into three types. These are (1) isolated clasts within the uppermost sediments, (2) glass shards within the sediments, and (3) volcanic rock samples (both basaltic and rhyolitic to dacitic) from the underlying volcanic units.

The uppermost cores from all three holes contain rhyolite and rhyodacite clasts. These clasts suggest that elsewhere (presumably upslope) volcanic units are exposed and are undergoing submarine erosion and transport. These samples are plagioclase-hornblende vitrophyric rhyolite and rhyodacite; they have a glassy groundmass, irregular vesicles, plagioclase microlites, and hornblende phenocrysts with embayed margins and opaque-rich coronae. Silicic volcanic units with identical textures were recovered from deeper levels in Holes $862 \mathrm{~B}$ and $862 \mathrm{C}$.

Within the sediments recovered from Holes $862 \mathrm{~A}$ and $862 \mathrm{~B}, 11$ layers were noted that had concentrations of pebble to sand-sized dark brown to black glass shards. In all cases, the glassy shards were enclosed within much finer, dominantly clayey silt (or siltstone) sedimentary lithologies. These sediments are interpreted to have been deposited during events of submarine glass spallation and dispersal via bottom currents. The events could represent submarine eruptions or tectonic disturbances.

Below the sedimentary cover, drilling recovered 103 fragments of the volcanic flows. Within these units, however, the core recovery was poor, ranging from $1 \%$ to $18 \%$. This poor recovery results in uncertainty regarding the potential correlation among holes, the relative abundance of types of units within the holes, and even the absolute order of units within any one core. Although the majority of the core fragments were too large to mix within the core barrel, few had

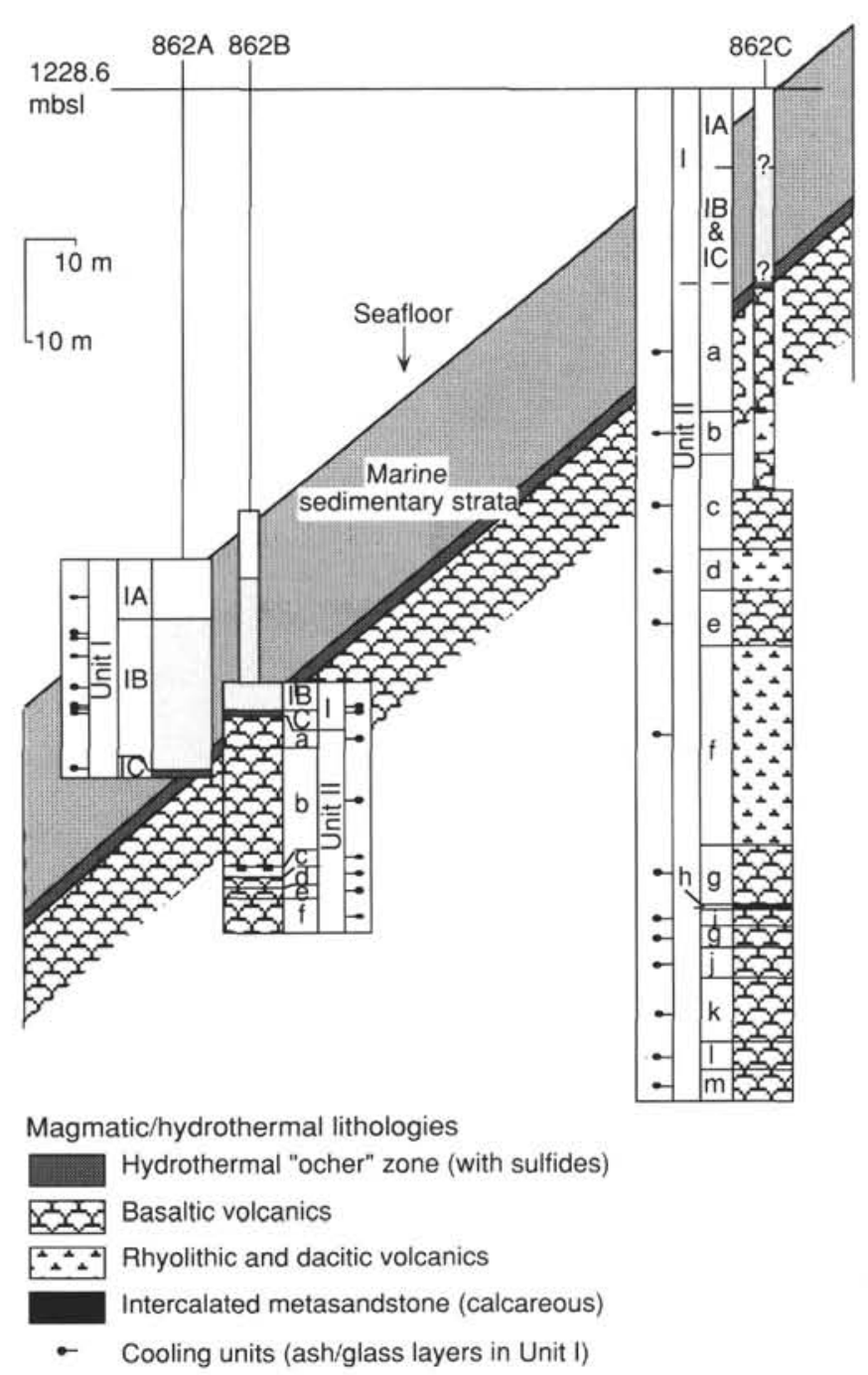

Figure 3. General unit stratigraphy for Holes $862 \mathrm{~A}, 862 \mathrm{~B}$ and $862 \mathrm{C}$ on the Taitao Ridge. Note vertical exaggeration. Presence of discrete eruptive events thought to be recorded by cooling units within the volcanic rocks are also shown. From Behrmann, Lewis, Musgrave, et al., 1992.

clear signs of having been cut by the core bit. The majority of fragments, therefore, were likely to have been produced in a zone of crushing near the advancing core bit. As the potential for downward mixing of units from higher stratigraphic level exists, new units were defined only at the appearance of new compositions or textural changes that clearly indicate a separate cooling unit. The application of textural and compositional criteria for defining cooling units resulted in a breakdown of the rock samples into seven cooling units within the $20 \mathrm{~m}$ of penetration of the basement at $862 \mathrm{~B}$, and 13 units within the 60 to $80 \mathrm{~m}$ of penetration at $862 \mathrm{C}$.

In general terms, the volcanic rock samples are of two petrographic types (Behrmann, Lewis, Musgrave, et al., 1992; Kurnosov et al., this volume). One type is represented by plagioclase-clinopyroxene-olivine phyric basalts, the other by moderately plagioclasehornblende phyric dacite, rhyodacite, and rhyolite. The basaltic rocks vary from samples with abundant volcanic glass at flow margins through more crystalline textures towards the interiors of the flow units. The groundmass is extensively devitrified within 1 to $2 \mathrm{~cm}$ of pillow margins. Most of the high silica samples have glomerophyric clusters of plagioclase and hornblende with a hyalopilitic (or pilotaxitic) to trachytic matrix containing aligned phenocrysts of plagioclase 
and hornblende and a glassy to microcystalline groundmass matrix of microlites of plagioclase. Most hornblende phenocrysts are variably embayed and surrounded by opaque-rich coronae.

\section{ANALYTICAL PROCEDURES}

Individual glass shards in sediments as well as the glass rinds on three basaltic flows were mounted in epoxy for electron microprobe analysis. The major-element compositions have been determined by wavelength dispersive spectrometers with the JEOL JXA-8600 electron microprobe at the University of Houston. The electron beam was defocused to $20 \mu \mathrm{m}$ in diameter, with a $20 \mathrm{nA}$ beam current. Counting times were $50 \mathrm{~s}$ on each peak and $25 \mathrm{~s}$ on each background position. Repetitive analyses of basaltic glasses under these conditions indicate that no $\mathrm{Na}_{2} \mathrm{O}$ migration occurred. Smithsonian Institution glass VG-2 was used as the primary standard for all oxides other than $\mathrm{TiO}_{2}, \mathrm{MnO}$, $\mathrm{K}_{2} \mathrm{O}$, and $\mathrm{P}_{2} \mathrm{O}_{5}$, for which ilmenite, rhodonite, sanidine, and apatite were used. The online Noran ZAF software was used to calculate concentrations from the intensity data. The reported analyses of glass rinds (Table 1) include the average and one standard deviation for 10 individual points; the reported analyses for glass shards (Table 2) typically are the average of three individual points analyzed on a given shard.

For the major element, trace element, and isotopic analyses reported in Tables 3, 4, and 5, glass rinds were removed from basalts and used to make sample powders. In addition, individual glass chips were separated from individual sediment layers and powdered. To make these powders, individual chips of glass were broken into pieces smaller than $1 \mathrm{~mm}$ and were washed ultrasonically in distilled water and ethanol. Phenocrysts and pieces of glass with surface alteration were removed by hand picking under a binocular microscope. The hand selected glass chips were rewashed, and ground to less than 100 mesh in an alumina mortar and pestle. Powders for the rhyolite samples were prepared in the same manner as the basaltic glasses. These basaltic and rhyolitic glass powders were analyzed at LamontDoherty Earth Observatory for $\mathrm{SiO}_{2}, \mathrm{Al}_{2} \mathrm{O}_{3}, \mathrm{CaO}, \mathrm{NaO}, \mathrm{K}_{2} \mathrm{O}, \mathrm{FeO}$, $\mathrm{MgO}, \mathrm{TiO}_{2}, \mathrm{MnO}, \mathrm{Sr}$, and $\mathrm{Ba}$ by direct current plasma emission spectrometry (DCPES). Analytical precision ( \pm 1 S.D.) of the DCPES data, based on replicate analyses of standards, is $0.5 \%$ (relative) for $\mathrm{SiO}_{2}, 1.0 \%$ for $\mathrm{Al}_{2} \mathrm{O}_{3}, 2.0 \%$ for $\mathrm{TiO}_{2}, 1.6 \%$ for $\mathrm{MgO}, 2.0 \%$ for $\mathrm{CaO}$, $1.4 \%$ for $\mathrm{MnO}, 1.2 \%$ for $\mathrm{Fe}_{2} \mathrm{O}_{3}, 1.5 \%$ for $\mathrm{Na}_{2} \mathrm{O}, 1.6 \%$ for $\mathrm{K}_{2} \mathrm{O}, 2.5 \%$ for $\mathrm{Ba}$, and $2.0 \%$ for $\mathrm{Sr}$.

Six samples ( 4 basalt glasses, 2 rhyolites) were analyzed for REEs by isotope dilution at the State University of New York at Stony Brook on a 9 in. radius, 90-sector mass spectrometer of NBS design. Sample powders $(300 \mathrm{mg})$ were fused with specially cleaned lithium metaborate flux in graphite crucibles, then dissolved in nitric acid that contained the REE spike. Precision is $1 \%$ for Ce, Nd, Sm, Dy, Er, and $\mathrm{Yb}$ and $2 \%$ for Eu and Gd. Chondrite normalized values used for the REE plots are listed in Table 4.

For isotopic analyses, $100-150 \mathrm{mg}$ of powdered samples were dissolved in HF in a capped Teflon beaker and, after evaporation to dryness, dissolved in the chloride form. One powdered aliquot was dissolved for analysis of $\mathrm{Sr}$ and Nd isotopic compositions; another for analysis of $\mathrm{Pb}$ isotopic composition and content. The latter, after dissolution in $\mathrm{HCl}$, was aliquoted and one aliquot mixed with $\mathrm{a}^{208} \mathrm{~Pb}$ enriched spike. $\mathrm{Sr}, \mathrm{Nd}$, and $\mathrm{Pb}$ were separated from other elements by standard ion-exchange chromatography.

Analyses were conducted on a VG Sector 54 8-collector solid source TIMS at the University of North Carolina at Chapel Hill. Pb was analyzed in static mode. $\mathrm{Sr}$ and $\mathrm{Nd}$ were analyzed using a triplecollection dynamic peak jumping mode. Replicate analyses of NBS 987 for ${ }^{87} \mathrm{Sr} /{ }^{86} \mathrm{Sr}$ average $0.710245 \pm 12(\sigma)$ normalized to ${ }^{86} \mathrm{Sr} /{ }^{88} \mathrm{Sr}=$ 0.1194 . Replicate analyses of Ames $\mathrm{Nd}$ standard for ${ }^{143} \mathrm{Nd} /{ }^{144} \mathrm{Nd}$ gave a value of $0.512136 \pm 18(\sigma)$, normalized to ${ }^{144} \mathrm{Nd} /{ }^{146} \mathrm{Nd}=0.7219$. ${ }^{145} \mathrm{Nd} /{ }^{144} \mathrm{Nd}$ of the standard was $0.348405 \pm 9 . \mathrm{Pb}$ analyses are normalized by $0.10 \%$ per mass unit difference relative to the mean value determined for NBS 981. Scatter in analyses of NBS 981 corresponds to an approximate $\sigma$ of $0.04 \%$ per mass unit difference in the ratio. Within-run errors are always much less than this. Sr analyses used a $3 \mathrm{~V}$ ${ }^{88} \mathrm{Sr}$ signal, $\mathrm{Nd}$ analyses used a $1 \mathrm{~V}{ }^{144} \mathrm{Nd}$ signal, and $\mathrm{Pb}$ analyses used a $2 \mathrm{~V}^{208} \mathrm{~Pb}$ signal (corresponding to a filament temperature of 1270 $1470^{\circ} \mathrm{C}$ ). Blanks are $60 \mathrm{\rho g}$ for $\mathrm{Nd} 200 \rho \mathrm{g}$ for $\mathrm{Sr}$, and $500 \rho \mathrm{g}$ for $\mathrm{Pb}$.

\section{RESULTS}

The compositions of glass rinds from Samples 141-862B-3X-1, 95-100 cm, and 141-862 B-X-CC, 3-38 cm, are similar in composition to many other mid-ocean ridge basalts (e.g., Bence et al., 1979). The glass rind on Sample 141-862C-W-01, 37-38 cm is distinctly different, however, and is characterized by high $\mathrm{SiO}_{2}(53.0 \%)$, low $\mathrm{FeO}^{*}(6.8 \%)$, high $\mathrm{K}_{2} \mathrm{O}(0.41 \%)$, and a high $\mathrm{Mg}$-number [100 $\mathrm{Mg}$ / $(\mathrm{Mg}+\mathrm{Fe})=65.3]$.

Glass shards were analyzed from seven sedimentary horizons overlying the volcanic units (here labeled 1A, 2A, 7A, 8A, 9A, 10A, and $11 \mathrm{~A})$. The sample intervals along with representative compositions of the shards are listed in Table 1. The number of glass shards in each sample varied from $<5$ to $>50$. Each analyzed shard was given a separate number, such that shard number 7A-19 in Table 1 was the nineteenth shard analyzed in sample 7A. There are three types of glass compositions that are very common as shards (Groups 1,2, and 5) and four types of glass compositions that are not abundant (Groups 3, 4, 6 , and 7). The compositions of ten representative shards are reported for the three most abundant groups in Table 1, whereas all shard compositions are reported for the remaining groups.

The Group 1 shards are very similar in composition to glass rind Samples 141-862B-3X-01, 95-100 cm, and 141-862B-X-CC, 3-38 $\mathrm{cm}$, and are inferred to be part of the same differentiation trend. The glass rind Sample 141-862C-W-1,37-38 cm, on the other hand, is very similar in composition to the Group 2 shards and is considered to be part of their differentiation trend. The Group 2 shards differ from the Group 1 shards by having higher $\mathrm{SiO}_{2}, \mathrm{Na}_{2} \mathrm{O}$, and $\mathrm{K}_{2} \mathrm{O}$, with lower $\mathrm{FeO} *, \mathrm{MgO}$, and $\mathrm{CaO}$ (Table 1). The Group 5 samples are intermediate in composition between the Group 1 and Group 2 shards. The major element chemical relationships between these various groups of basaltic glasses are shown in Figures 4A through 4G. Because Groups 1 and 2 define the range of basaltic compositions for these samples, most of the subsequent discussion focuses on their compositions.

The remaining glass shards (Groups 3, 4, 6, and 7) are relatively rare and are difficult to directly link to local submarine volcanism on the Taitao Ridge because of the absence of recovered basaltic flows whose compositions match these groups. The andesites, dacites, and rhyolites (Group 7), might even be related to nearby continental volcanism rather than silicic ocean floor volcanism.

The major-element, $\mathrm{Sr}$, and $\mathrm{Ba}$ compositions of eight basaltic glass samples are listed in Table 3. Also shown in Table 3 is the glass shard group to which the whole-rock analyses are considered to be related. For the same glass sample, differences between the microprobe glass compositions (Tables 1 and 2) and the hand-picked glass separates (Table 3 ) are attributed to phenocrysts too small to have been removed by the procedures used. As with the microprobe analyses, the DCPES data also indicate that the Group 1 glasses (Samples 141-862B-X-CC, 3-38 cm, and 141-862B-3X-1, 95-100 cm) have higher $\mathrm{CaO}$ and $\mathrm{FeO}^{*}$ as well as lower $\mathrm{SiO}_{2}, \mathrm{Na}_{2} \mathrm{O}$, and $\mathrm{K}_{2} \mathrm{O}$ at the same $\mathrm{MgO}$ content. In addition, Group 1 basalts are characterized by distinctly lower $\mathrm{Sr}$ and $\mathrm{Ba}$ abundances than Group 2 basalts (Table 3 ).

REE concentrations for four basalts and two rhyolites are shown in Table 4 and have been illustrated as chondrite normalized diagrams in Figures 5A and 5B, respectively. The REE pattern for Group 1 basalt, (Sample 141-862B-3X-1, 95-100 cm) is characterized by a strong light $\mathrm{REE}$ depletion $\left(\mathrm{Ce}_{\mathrm{N}} / \mathrm{Yb}_{\mathrm{N}}=0.6\right)$, and no Eu anomaly. The three basalt glasses related to the Group 2 glasses (Fig. 5A) exhibit light REE-enriched patterns $\left(\mathrm{Ce}_{\mathrm{N}} / \mathrm{Yb}_{\mathrm{N}}=1.4-1.5\right)$ and slight $\mathrm{Eu}$ anomalies. The two rhyolite samples illustrated in Figure $5 \mathrm{~B}$ have 
Table 1. Electron microprobe analysis of glass rinds on phyric basalt samples, Site 862, Taitao Ridge.

\begin{tabular}{|c|c|c|c|c|c|c|}
\hline & \multicolumn{2}{|c|}{$141-862 \mathrm{~B}-3 \mathrm{X}-1,95-100 \mathrm{~cm}$} & \multicolumn{2}{|c|}{$141-862 \mathrm{~B}-2 \mathrm{X}-\mathrm{CC}, 3-38 \mathrm{~cm}$} & \multicolumn{2}{|c|}{$141-862 \mathrm{C}-1 \mathrm{~W}-1,37-38 \mathrm{~cm}$} \\
\hline & Average & I S.D. & Average & I S.D. & Average & 1 S.D. \\
\hline \multicolumn{7}{|c|}{ Major elements (wt\%) } \\
\hline $\mathrm{SiO}_{2}$ & 50.65 & 0.31 & 50.82 & 0.2 & 53.02 & 0.16 \\
\hline $\mathrm{TiO}_{2}^{2}$ & 1.19 & 0.05 & 1.2 & 0.06 & 1.08 & 0.05 \\
\hline $\mathrm{Al}_{2} \mathrm{O}_{3}$ & 16.88 & 0.12 & 16.68 & 0.05 & 17.35 & 0.07 \\
\hline $\mathrm{FeO}$ & 8.42 & 0.12 & 8.44 & 0.09 & 6.78 & 0.06 \\
\hline $\mathrm{MnO}$ & 0.16 & 0.02 & 0.16 & 0.01 & 0.13 & 0.01 \\
\hline $\mathrm{MgO}$ & 8.14 & 0.06 & 8.16 & 0.06 & 7.15 & 0.04 \\
\hline $\mathrm{CaO}$ & 11.86 & 0.08 & 11.88 & 0.03 & 10.29 & 0.03 \\
\hline $\mathrm{Na}_{2} \mathrm{O}$ & 2.77 & 0.14 & 2.91 & 0.03 & 3.29 & 0.03 \\
\hline $\mathrm{K}_{2} \mathrm{O}$ & 0.05 & 0.01 & 0.04 & 0.01 & 0.41 & 0.01 \\
\hline $\mathrm{P}_{2} \mathrm{O}_{5}$ & 0.1 & 0.01 & 0.09 & 0.01 & 0.12 & 0.01 \\
\hline Total & 100.21 & & 100.38 & & 99.59 & \\
\hline $\mathrm{Mg \#}$ & 63.3 & 63.3 & & 65.3 & & \\
\hline
\end{tabular}

Note: S.D. = standard deviation.

REE patterns characterized by high Ce abundances $(\times 45-50$ chondrites), negative Eu anomalies, and heavy REE abundances that are approximately $25 \%$ lower than those of any of the basalts analyzed.

$\mathrm{Sr}, \mathrm{Nd}$, and $\mathrm{Pb}$ isotopic compositions have been determined for six samples (Table 5). The single Group 1 basalt for which isotopic compositions have been determined (Fig. 6) has Sr-Nd systematics similar to those of many MORB from the MAR and EPR $\left({ }^{87} \mathrm{Sr} /{ }^{86} \mathrm{Sr} \cong\right.$ $0.7028, \varepsilon_{\mathrm{Nd}} \cong+0.7$ ). The three Group 2 basalts, however, have distinctly different $\mathrm{Sr}-\mathrm{Nd}$ compositions at ${ }^{87} \mathrm{Sr} /{ }^{86} \mathrm{Sr}=0.7033, \varepsilon_{\mathrm{Nd}} \cong+8.0$. The two rhyolites analyzed differ in isotopic composition from the basalts with much higher ${ }^{87} \mathrm{Sr} /{ }^{86} \mathrm{Sr}(\cong 0.7041)$.

Figures $7 \mathrm{~A}$ and $7 \mathrm{~B}$ show $\mathrm{Pb}$ isotopic variations in the same six samples. The Group 1 basalt has the lowest values of ${ }^{206} \mathrm{~Pb} /{ }^{204} \mathrm{~Pb}$, ${ }^{207} \mathrm{~Pb} /{ }^{204} \mathrm{~Pb}$ and ${ }^{208} \mathrm{~Pb} /{ }^{204} \mathrm{~Pb}$ of the six samples analyzed. This sample is displaced from the Northern Hemisphere Reference Line (NHRL) on Figure $7 \mathrm{~A}$ with higher ${ }^{207} \mathrm{~Pb} /{ }^{204} \mathrm{~Pb}$ than most MORBs. Some other Nazca Plate basalts are similarly displaced to higher ${ }^{207} \mathrm{~Pb} /{ }^{204} \mathrm{~Pb}$ than the NHRL, although at higher ${ }^{206} \mathrm{~Pb} /{ }^{204} \mathrm{~Pb}$. The ${ }^{208} \mathrm{~Pb} /{ }^{204} \mathrm{~Pb}-$ ${ }^{206} \mathrm{~Pb} /{ }^{204} \mathrm{~Pb}$ relations of the Group 1 basalt are near the NHRL. The Group 2 basalts and the rhyolites have similar $\mathrm{Pb}$ isotopic ratios (Figs. 7A and 7B). They are highter in ${ }^{207} \mathrm{~Pb} /{ }^{204} \mathrm{~Pb}$ than the NHRL or Nazca Plate basalts and have higher ${ }^{208} \mathrm{~Pb} /{ }^{204} \mathrm{~Pb}$.

\section{INTERPRETATION}

Upon consideration of the geochemical data, we consider three questions related to magmatic activity at the Taitao Ridge:

1. What are the differentiation processes responsible for producing the geochemical variations within the Group 1 and Group 2 glasses?

2. What do the first-order differences between Group 1 and Group 2 glasses indicate about magmatism at the Taitao Ridge?

3. What is the petrogenesis of the silicic lavas?

In addition, we discuss the insights that the geochemistry of these samples yield into the tectonics of the Taitao Ridge.

\section{Differentiation Processes}

Numerous studies of MORBs have shown that low-pressure crystallization of olivine, plagioclase, and (sometimes) augitic clinopyroxene controls the liquid line of descent in these magmas (e.g., Bryan, 1979; Grove and Bryan, 1983; Perfit and Fornari, 1983). Because no experimental studies of the crystallization of these Taitao Ridge samples have been undertaken, the 1 ATM liquid lines of descent for these samples have been calculated by the CHAOS5 algorithm of Neilsen (1988). The calculated liquid lines of descent for estimated parental magmas for glasses from Groups 1 and 2 are listed in Table 6 and are compared with the variations in glass compositions in Figures 4A through 4G.
The 1 ATM liquid lines of descent for parental magmas for Groups 1 and 2 are characterized by a small interval of plagioclase-only crystallization, followed by an extended interval of olivine + plagioclase crystallization, and then olivine + plagioclase + clinopyroxene. This sequence of crystallization is common amongst MORBs (Bryan, 1979; Grove and Bryan, 1983; Grove and Juster, 1989). The plagioclase-only crystallization interval (Figs. $4 \mathrm{~A}$ through $4 \mathrm{G}$ ) is characterized by an increase in $\mathrm{MgO}$ and other oxides that are not compatible in plagioclase, along with a decrease in $\mathrm{Al}_{2} \mathrm{O}_{3}$ and $\mathrm{CaO}$. The remainder of the liquid lines of descent shown in Figures 4A through $4 \mathrm{G}$ for the Group 2 parental magma is for olivine + plagioclase crystallization; the onset of clinopyroxene crystallization in these parental magmas does not occur until the residual liquid has $5.6 \% \mathrm{MgO}$ (Table 6). The onset of clinopyroxene crystallization in the parental magma for Group 1 occurs at $7.1 \% \mathrm{MgO}$ (Table 6), as clearly shown by the decreasing $\mathrm{CaO}$ content in Figure 4E.

The initial small interval of plagioclase-only crystallization for these three parental magmas results in a displacement of the calculated liquid lines of descent away from the trend of the glass shards. This effect is shown for $\mathrm{CaO}$ in Figure 4E, where the initial interval of plagioclase-only crystallization increases the $\mathrm{MgO}$ content and decreases the $\mathrm{CaO}$ content, and then olivine + plagioclase crystallization reduces the $\mathrm{MgO}$ content while $\mathrm{CaO}$ increases slightly. The calculated liquid lines of descent are parallel to but slightly lower in $\mathrm{CaO}$ than the trends of the glass compositions (Fig. 4E). A comparable effect is also seen in $\mathrm{FeO}^{*}$ versus $\mathrm{MgO}$ space (Fig. 4D), in which the calculated liquid lines of descent are displaced to higher $\mathrm{FeO}^{*}$ than the trend of the composition of the glass shard.

The three samples of basaltic glass rinds all have abundant olivine and plagioclase phenocrysts, suggesting that these liquid compositions were co-saturated with these two minerals at the time of eruption and quenching. The glass shards, on the other hand, are typically only a few tens of microns across and do not have mineral phases associated with them; it is not possible to determine their phenocryst minerals under magmatic conditions. In light of the petrographic evidence indicating that the Taitao Ridge glasses are at or near cosaturation in plagioclase and olivine at the time of eruption, it is possible that this calculated small interval of plagioclase-only crystallization is the erroneous result of imperfect knowledge of plagioclase saturation surfaces in basaltic liquids. It is also possible that a small amount of water in the natural basaltic liquid $(0.3 \mathrm{wt} \%)$ would suppress the crystallization of this small amount of plagioclase so that the liquid would actually be co-saturated in olivine and plagioclase under magmatic conditions (fig. 11 of Michael and Chase, 1987).

The usefulness of these calculated liquid lines of descent in interpreting the chemical variations in the glass shards is that the slopes of the lines can be used to determine the minerals that have crystallized to form the glass trend. The variations in basalt glass compositions are shown in Figures $8 \mathrm{~A}$ through $8 \mathrm{G}$, in which liquid lines of descent for 
Table 2. Electron microprobe analysis of glasses, Hole 862A, Taitao Ridge.

\begin{tabular}{|c|c|c|c|c|c|c|c|c|c|c|c|c|}
\hline \multirow{4}{*}{$\begin{array}{l}\text { Core, section: } \\
\text { Interval }(\mathrm{cm}) \text { : } \\
\text { Shard no: }\end{array}$} & \multicolumn{9}{|c|}{ Group 1} & \multirow[b]{2}{*}{$4 \mathrm{H}-1$} & \multicolumn{2}{|c|}{ Group 2} \\
\hline & $3 \mathrm{H}-\mathrm{I}$ & $2 \mathrm{H}-2$ & $3 \mathrm{H}-\mathrm{I}$ & $4 \mathrm{H}-1$ & $3 \mathrm{H}-1$ & $4 \mathrm{H}-1$ & $4 \mathrm{H}-1$ & $4 \mathrm{H}-1$ & $4 \mathrm{H}-1$ & & $3 \mathrm{H}-\mathrm{I}$ & $2 \mathrm{H}-2$ \\
\hline & $27-29$ & $24-26$ & $27-29$ & $17-20$ & $27-29$ & $17-20$ & $17-20$ & $17-20$ & $17-20$ & $17-20$ & $6-8$ & $24-26$ \\
\hline & $7 \mathrm{~A}-19$ & $2 \mathrm{~A}-6$ & $7 \mathrm{~A}-4$ & $|A-|$ & $7 A-18$ & IA-8 & IA-9 & IA-6 & $1 \mathrm{~A}-2$ & $1 \mathrm{~A}-3$ & $11 \mathrm{~A}-6$ & $2 \mathrm{~A}-2$ \\
\hline \multicolumn{13}{|c|}{ Major elements (wt\%) } \\
\hline $\mathrm{SiO}_{2}$ & 50.64 & 50.84 & 51.17 & 51.49 & 51.05 & 51.28 & 51.34 & 51.04 & 51.26 & 51.28 & 51.83 & 52.92 \\
\hline $\mathrm{TiO}_{2}^{-}$ & 1.11 & 1.02 & 1.05 & 1.14 & 1.15 & 1.2 & 1.22 & 1.26 & 1.28 & 1.3 & 1 & 1.04 \\
\hline $\mathrm{Al}_{2} \mathrm{O}_{3}$ & 17.08 & 17.41 & 17.19 & 16.47 & 16.77 & 16.54 & 16.59 & 16.84 & 16.54 & 16.49 & 17.24 & 17.2 \\
\hline $\mathrm{FeO}$ & 8.07 & 8.09 & 7.89 & 8.41 & 8.28 & 8.31 & 8.36 & 8.39 & 8.47 & 8.41 & 6.97 & 6.85 \\
\hline $\mathrm{MnO}$ & 0.16 & 0.15 & 0.15 & 0.17 & 0.17 & 0.15 & 0.17 & 0.15 & 0.16 & 0.17 & 0.14 & 0.12 \\
\hline $\mathrm{MgO}$ & 8.55 & 8.52 & 8.42 & 8.21 & 8.25 & 8.16 & 8.22 & 8.21 & 8.16 & 8.16 & 8.14 & 8.09 \\
\hline $\mathrm{CaO}$ & 12.04 & 11.82 & 11.74 & 11.9 & 11.98 & 11.86 & 11.86 & 11.92 & 11.94 & 11.95 & 10.13 & 10.16 \\
\hline $\mathrm{Na}_{2} \mathrm{O}$ & 2.86 & 2.94 & 2.94 & 2.92 & 2.96 & 2.88 & 2.93 & 2.97 & 2.88 & 2.91 & 3.2 & 3.2 \\
\hline $\mathrm{K}_{2} \tilde{\mathrm{O}}$ & 0.03 & 0.06 & 0.08 & 0.04 & 0.04 & 0.05 & 0.06 & 0.05 & 0.05 & 0.05 & 0.4 & 0.4 \\
\hline $\mathrm{P}_{2} \mathrm{O}_{5}$ & 0.07 & 0.08 & 0.1 & 0.08 & 0.09 & 0.09 & 0.09 & 0.08 & 0.11 & 0.1 & 0.12 & 0.13 \\
\hline Total & 100.59 & 100.91 & 100.7 & 100.83 & 100.71 & 100.49 & 100.81 & 100.88 & 100.82 & 100.8 & 99.15 & 100.06 \\
\hline $\mathrm{Mg \#}$ & 65.37 & 65.24 & 6.5 .54 & 63.5 & 63.96 & 63.64 & 63.66 & 63.56 & 63.18 & 63.36 & 67.55 & 67.8 \\
\hline
\end{tabular}

Note: Group I = low K basaltic glass shards, 10 representative samples; Group 2 = high K basaltic glass shards, 10 representative samples: Group $5=10$ representative samples: Group 7 = andesites, dacites, and hyolites. Groups 3-6: descriptions not available: noted rare but not discussed in any descriptive way.

Table 2 (continued).

\begin{tabular}{|c|c|c|c|c|c|c|c|c|c|c|c|c|c|}
\hline \multirow{4}{*}{$\begin{array}{l}\text { Core, section: } \\
\text { Interval }(\mathrm{cm}) \text { : } \\
\text { Shard no.: }\end{array}$} & \multicolumn{3}{|c|}{ Group 4} & \multicolumn{10}{|c|}{ Group 5} \\
\hline & $2 \mathrm{H}-2$ & $2 \mathrm{H}-2$ & $3 \mathrm{H}-\mathrm{I}$ & $3 \mathrm{H}, \mathrm{I}$ & $3 \mathrm{H} . \mathrm{I}$ & $3 \mathrm{H}, \mathrm{I}$ & $3 \mathrm{H} . \mathrm{I}$ & $3 \mathrm{H}, \mathrm{I}$ & $3 \mathrm{H} . \mathrm{I}$ & $3 \mathrm{H}, \mathrm{I}$ & $3 \mathrm{H}, \mathrm{I}$ & $3 \mathrm{H}, \mathrm{I}$ & $3 \mathrm{H}, \mathrm{I}$ \\
\hline & $24-26$ & $24-26$ & $6-8$ & $6-8$ & $27-29$ & $27-29$ & $6-8$ & $27-29$ & $6-8$ & $6-8$ & $60-62$ & $27-29$ & $6-8$ \\
\hline & $2 \mathrm{~A}-3$ & $2 \mathrm{~A}-4$ & $11 \mathrm{~A}-5$ & $11 \mathrm{~A}-13$ & $7 A-6$ & $7 \mathrm{~A}-3$ & $11 \mathrm{~A}-7$ & $7 \mathrm{~A}-12$ & $11 \mathrm{~A}-4$ & $11 A-16$ & $8 \mathrm{~A}-7$ & $7 A-15$ & $11 \mathrm{~A}-14$ \\
\hline \multicolumn{14}{|c|}{ Major elements (wt\%) } \\
\hline $\mathrm{SiO}_{2}$ & 51.89 & 51.88 & 50.99 & 51.35 & 52.33 & 52.07 & 51.39 & 51.77 & 51.18 & 51.66 & 52.88 & 52.58 & 51.64 \\
\hline $\mathrm{TiO}_{2}^{-}$ & 1.36 & 1.39 & 1.46 & 1.05 & 1.03 & 1.1 & 1.16 & 1.19 & 1.13 & 1.17 & 1.12 & 1.09 & 1.16 \\
\hline $\mathrm{Al}_{2} \mathrm{O}_{3}$ & 16.12 & 16 & 15.7 & 17.23 & 17.12 & 17.04 & 17.33 & 17.36 & 17.47 & 17.33 & 17.35 & 17.24 & 17.24 \\
\hline $\mathrm{FeO}$ & 8.79 & 8.78 & 9.28 & 7.22 & 7.28 & 7.45 & 7.31 & 7.29 & 7.34 & 7.18 & 7.27 & 7.18 & 7.43 \\
\hline $\mathrm{MnO}$ & 0.18 & 0.19 & 0.18 & 0.15 & 0.13 & 0.12 & 0.13 & 0.15 & 0.13 & 0.15 & 0.14 & 0.13 & 0.15 \\
\hline $\mathrm{MgO}$ & 7.46 & 7.4 & 7.21 & 8.38 & 8.37 & 8.15 & 7.97 & 7.91 & 7.79 & 7.88 & 7.63 & 7.57 & 7.08 \\
\hline $\mathrm{CaO}$ & 11.35 & 11.31 & 11.25 & 10.56 & 10.58 & 10.91 & 10.52 & 10.93 & 10.51 & 10.58 & 10.54 & 10.45 & 10.62 \\
\hline $\mathrm{Na}_{2} \mathrm{O}$ & 2.95 & 2.86 & 2.95 & 3,12 & 3.11 & 3.04 & 3.25 & 3.18 & 3.3 & 3.23 & 3.38 & 3.27 & 3.4 \\
\hline $\mathrm{K}_{2} \mathrm{O}$ & 0.22 & 0.22 & 0.23 & 0.3 & 0.31 & 0.25 & 0.3 & 0.25 & 0.32 & 0.3 & 0.31 & 0.34 & 0.33 \\
\hline $\mathrm{P}_{2} \mathrm{O}_{5}$ & 0.16 & 0.14 & 0.14 & 0.11 & 0.12 & 0.11 & 0.13 & 0.11 & 0.1 & 0.13 & 0.13 & 0.12 & 0.13 \\
\hline Total & 100.45 & 100.16 & 99.35 & 99.45 & 100.36 & 100.23 & 99.48 & 100.12 & 99.26 & 99.59 & 100.75 & 99.94 & 99.17 \\
\hline $\mathrm{Mg} \#$ & 60.19 & 60.02 & 58.08 & 67.41 & 67.21 & 66.12 & 66.03 & 65.93 & 65.43 & 66.16 & 65.19 & 65.27 & 62.94 \\
\hline
\end{tabular}

olivine + plagioclase crystallization are shown starting from parental magmas for the Group 1 and Group 2 glasses (i.e., these liquid lines of descent do not have the initial small interval of plagioclase-only crystallization, but retain the appropriate slopes for olivine + plagioclase crystallization). The $\mathrm{Al}_{2} \mathrm{O}_{3}$ contents of the Group 1 glasses progressively decrease as $\mathrm{MgO}$ decreases (Fig. $8 \mathrm{C}$ ), and the $\mathrm{FeO} *$ contents increase as $\mathrm{MgO}$ decreases (Fig. 8D), comparable in slope to olivine + plagioclase co-crystallization. The variations in other major element oxides in the Group 1 glasses have similar slopes to that shown for olivine + plagioclase crystallization (see Figs. 8A, 8B, $8 \mathrm{E}, 8 \mathrm{~F}$, and $8 \mathrm{G})$. The normal proportion of olivine to plagioclase during their co-crystallization from basalts, as deduced from experimental studies (e.g., Grove and Bryan, 1983; Juster and Grove, 1985) or from the slope of the liquid line of descent for $\mathrm{MgO}$ versus $\mathrm{Al}_{2} \mathrm{O}_{3}$ (Figs. 4C and 8C) is 2:1.

The chemical variations in Group 2 glasses, on the contrary, do not seem to be explicable in terms of relatively simple low-pressure crystallization processes. It appears that the trend of Group 2 glass compositions does not involve olivine + plagioclase + clinopyroxene crystallization in normal low-pressure anhydrous cotectic proportions because these glasses have nearly uniform $\mathrm{CaO}$ contents, whereas the $\mathrm{CaO}$ content of residual glasses should decrease substantially during olivine + plagioclase + clinopyroxene crystallization (compare Figs. $4 \mathrm{E}$ and $8 \mathrm{E}$ ). Similarly, the nearly constant $\mathrm{Al}_{2} \mathrm{O}_{3}$ and FeO* contents of Group 2 glasses appear to preclude the crystallization of plagioclase, olivine + plagioclase, or olivine + plagioclase + clinopyroxene in normal cotectic proportions because these types of crystallization produce residual liquids with progressively lower $\mathrm{Al}_{2} \mathrm{O}_{3}$ contents (compare Figs. $4 \mathrm{C}, 4 \mathrm{D}, 8 \mathrm{C}$ and $8 \mathrm{D}$ ). In addition, the trends in the Group 2 glasses are not likely to result from crystal- lization at elevated pressures because the principal effect of increasing pressure is to cause clinopyroxene to move closer to the liquidus of the basaltic composition. The constant $\mathrm{CaO}$ content throughout the range of crystallization of Group 2 glasses rules out this possibility.

Alternatively, the compositional trend for Group 2 glasses was produced by crystallization of olivine + plagioclase in proportions that differ markedly from $2: 1$. If the proportion is $1: 1$ by weight for olivine + plagioclase crystallization, the $\mathrm{Al}_{2} \mathrm{O}_{3}, \mathrm{FeO}$, and $\mathrm{CaO}$ contents of residual liquids remain nearly constant (see Fig. 8 and Table 7).

\section{Magmatic Implications of the Differences between Basalt Groups 1 and 2}

There are several fundamental differences between Group 1 and Group 2 basalts. Major and trace element and isotopic differences between these two groups are so great that the two groups cannot be related by simple solid-liquid processes and different sources are required for Group 1 and Group 2 basalts.

In addition to element-element diagrams (Figs. 4 and 8), Figure 9 is used to illustrate major-element variations in the glasses on a conventional AFM diagram. Samples within each of the populous groups $(1,2,5)$ show limited variations on this diagram. The most magnesian samples of each group have similar relative amounts of 'M' but are displaced to lower A:F in the order Group 1, Group 5, Group 2. This reflects not only the progressively higher $\mathrm{K}_{2} \mathrm{O}$ and $\mathrm{Na}_{2} \mathrm{O}$ contents in the Groups 1,5, and 2 (Figs. $4 \mathrm{~F}$ and $4 \mathrm{G}$ ) but also the decrease of $\mathrm{FeO}^{*}$ in the same order (Fig. 4D). All samples are more Fe-poor than the tholeiite-calc-alkaline dividing line of Irvine and Baragar (1971) and so all groups are calc-alkaline by this definition. Moreover, the Groups 2 and 5 samples define trends on the AFM that are much 
Table 2 (continued).

\begin{tabular}{|c|c|c|c|c|c|c|c|c|c|c|c|c|c|}
\hline \multirow{4}{*}{$\begin{array}{l}\text { Core. section: } \\
\text { Interval }(\mathrm{cm}) \text { : } \\
\text { Shard no.: }\end{array}$} & \multicolumn{7}{|c|}{ Group 2} & \multirow[b]{2}{*}{$2 \mathrm{H}-2$} & \multicolumn{5}{|c|}{ Group 3} \\
\hline & $3 \mathrm{H}-1$ & $3 \mathrm{H}-1$ & $1 \mathrm{H}-3$ & $3 \mathrm{H}-\mathrm{I}$ & $3 \mathrm{H}-\mathrm{I}$ & $3 \mathrm{H}-1$ & $2 \mathrm{H}-2$ & & $3 \mathrm{H}-1$ & $3 \mathrm{H}-\mathrm{I}$ & $3 \mathrm{H}-1$ & $3 \mathrm{H}-\mathrm{I}$ & $3 \mathrm{H}-1$ \\
\hline & $6-8$ & $27-29$ & $73-75$ & $27-29$ & $27-29$ & $60-62$ & $24-26$ & $24-26$ & $27-29$ & $60-62$ & $60-62$ & $60-62$ & $27-29$ \\
\hline & $11 \mathrm{~A}-2$ & $7 A-2$ & $9 \mathrm{~A}-4$ & $7 A-16$ & $7 \mathrm{~A}-9$ & $8 A-1$ & $2 \mathrm{~A}-8$ & $2 \mathrm{~A}-1$ & $7 \AA-5$ & $8 \mathrm{~A}-3$ & $8 \mathrm{~A}-5$ & $8 \mathrm{~A}-8$ & $7 A-8$ \\
\hline \multicolumn{14}{|c|}{ Major elements (wt\%) } \\
\hline $\mathrm{SiO}_{2}$ & 51.87 & 52.93 & 52.6 & 52.91 & 5.3 .57 & 52.17 & 52.72 & 53.28 & 51.84 & 51.86 & 52.17 & 52.25 & 52.28 \\
\hline $\mathrm{TiO}_{2}^{-}$ & 1.06 & 1.05 & 1.05 & 1.06 & 1 & 1.07 & 1.2 & 1.28 & 1.18 & 1.08 & 1.09 & 1.1 & 1.19 \\
\hline $\mathrm{Al}_{2} \mathrm{O}_{3}$ & 17.12 & 17.14 & 17.45 & 17.29 & 17.23 & 17.12 & 17.59 & 17.26 & 16.8 & 16.95 & 16.96 & 17.02 & 16.79 \\
\hline $\mathrm{FeO}$ & 6.88 & 6.89 & 6.89 & 6.82 & 6.75 & 7.06 & 7.03 & 7.14 & 7.93 & 7.67 & 7.75 & 7.69 & 7.85 \\
\hline $\mathrm{MnO}$ & 0.14 & 0.13 & 0.13 & 0.13 & 0.12 & 0.13 & 0.13 & 0.13 & 0.12 & 0.15 & 0.15 & 0.16 & 0.14 \\
\hline $\mathrm{MgO}$ & 8.05 & 7.96 & 7.92 & 7.78 & 7.74 & 7.6 & 6.87 & 6.7 & 7.73 & 7.8 & 7.7 & 7.85 & 7.73 \\
\hline $\mathrm{CaO}$ & 10.15 & 10.22 & 10.28 & 10.28 & 10.3 & 10.27 & 10.31 & 10.28 & 11.35 & 11.4 & 11.36 & 11.34 & 11.35 \\
\hline $\mathrm{Na}_{2} \mathrm{O}$ & 3.19 & 3.14 & 3.21 & 3.2 & 3.2 & 3.37 & 3.64 & 3.67 & 3.04 & 3.13 & 3.18 & 3.17 & 3.09 \\
\hline $\mathrm{K}_{2} \mathrm{O}$ & 0.39 & 0.39 & 0.40 & 0.39 & 0.39 & 0.36 & 0.36 & 0.36 & 0.19 & 0.19 & 0.2 & 0.2 & 0.18 \\
\hline $\mathrm{P}_{2} \mathrm{O}_{5}$ & 0.12 & 0.12 & 0.11 & 0.11 & 0.12 & 0.13 & 0.11 & 0.12 & 0.1 & 0.09 & 0.1 & 0.12 & 0.12 \\
\hline Total & 98.94 & 99.95 & 100.03 & 99.94 & 100.4 & 99.27 & 99.93 & 100.2 & 100.26 & $|00.3|$ & 100.65 & 100.89 & 100.69 \\
\hline Mg\#\# & 67.61 & 67.31 & 67.2 & 67.05 & 67.15 & 65.73 & 6.3 .53 & 62.56 & 63,48 & 64,45 & 63.93 & 64.53 & 63.72 \\
\hline
\end{tabular}

Table 2 (continued).

\begin{tabular}{|c|c|c|c|c|c|c|c|}
\hline \multirow{4}{*}{$\begin{array}{l}\text { Core, section: } \\
\text { Interval }(\mathrm{cm}) \text { : } \\
\text { Shard no: }\end{array}$} & \multirow{3}{*}{$\begin{array}{c}\text { Group } 6 \\
\begin{array}{c}3 \mathrm{H}-1 \\
6-8\end{array}\end{array}$} & \multicolumn{6}{|c|}{ Group 7} \\
\hline & & $2 \mathrm{H}-2$ & $2 \mathrm{H}-2$ & $3 \mathrm{H}-1$ & $3 \mathrm{H}-\mathrm{I}$ & $2 \mathrm{H}-2$ & $3 \mathrm{H}-1$ \\
\hline & & $24-26$ & $24-26$ & $27-29$ & $27-29$ & $24-26$ & $60-62$ \\
\hline & $11 \mathrm{~A}-10$ & $2 \mathrm{~A}-5$ & $2 A-9$ & $7 A-17$ & $7 A-10$ & $2 \mathrm{~A}-7$ & $8 A-11$ \\
\hline \multicolumn{8}{|c|}{ Major elements (wt\%) } \\
\hline $\mathrm{SiO}_{2}$ & 51.28 & 55.61 & 58.49 & 59.93 & 60.54 & 74.75 & 78.38 \\
\hline $\mathrm{TiO}_{2}^{-}$ & 1.58 & 1.06 & 1.94 & 1.09 & 1.05 & 0.36 & 0.41 \\
\hline $\mathrm{Al}_{2} \mathrm{O}_{3}$ & 16.68 & 17.03 & 16.01 & 16.55 & 16.43 & 11.9 & 11.59 \\
\hline $\mathrm{FeO}$ & 8.3 & 6.3 & 7.89 & 5.4 & 5.5 & 1.47 & 1.64 \\
\hline $\mathrm{MnO}$ & 0.17 & 0.1 & 0.16 & 0.11 & 0.08 & 0.02 & 0,04 \\
\hline $\mathrm{MgO}$ & 6.93 & 5.56 & 2.99 & 3.75 & 3.73 & 0.18 & 0.19 \\
\hline $\mathrm{CaO}$ & 10.42 & 9.77 & 6.36 & 6.96 & 6.93 & 0.84 & 0.8 \\
\hline $\mathrm{Na}_{2} \mathrm{O}$ & 3.66 & 3.69 & 4.26 & 3.84 & 3.84 & 2.77 & 2.46 \\
\hline $\mathrm{K}_{2} \mathrm{O}$ & 0.18 & 0.59 & 1.02 & 1.12 & 1.14 & 3.53 & 2.85 \\
\hline $\mathrm{P}_{2} \mathrm{O}_{5}$ & 0.15 & 0.13 & 0.25 & 0.15 & 0.14 & 0.04 & 0.06 \\
\hline Total & 99,34 & 99.81 & 99.35 & 98.89 & 99.36 & 95.84 & 98.42 \\
\hline $\mathrm{Mg \#}$ & 59.81 & 61.15 & 40.29 & 55.32 & 54.75 & 17.92 & 15.51 \\
\hline
\end{tabular}

Table 3. DCPES analyses of Site 862 volcanic samples.

\begin{tabular}{|c|c|c|c|c|c|c|c|c|}
\hline Hole: & $862 \mathrm{~A}$ & $862 \mathrm{~A}$ & $862 B$ & $862 \mathrm{~B}$ & $862 B$ & $862 \mathrm{C}$ & $862 \mathrm{C}$ & $862 X$ \\
\hline Core, section: & $3 \mathrm{H}-\mathrm{I}$ & $01 \mathrm{~A}-2$ & $2 \mathrm{X}-\mathrm{CC}$ & $3 X-1$ & $4 \times-2$ & $1 W-1$ & $6 R-1$ & $8 R-1$ \\
\hline \multicolumn{9}{|c|}{ Major elements (wt\%) } \\
\hline $\mathrm{SiO}_{2}$ & 50.35 & 52.11 & 49.01 & 49.57 & 51.72 & 53.19 & 52.03 & 51.23 \\
\hline $\mathrm{TiO}_{2}^{-}$ & 1.06 & 1.1 & 1.05 & 1.06 & 1.17 & 1.12 & 1 & 1.22 \\
\hline $\mathrm{Al}_{2} \overline{\mathrm{O}}_{3}$ & 16.41 & 16.87 & 17.08 & 16.95 & 16.22 & 18.28 & 16.55 & 16.43 \\
\hline $\mathrm{Fe}_{2} \mathrm{O}_{3}$ & 7.81 & 7.98 & 8.56 & 8.92 & 8.56 & 6.57 & 7.74 & 8.53 \\
\hline $\mathrm{MnO} O$ & 0.13 & 0.134 & 0.141 & 0.142 & 0.124 & 0.102 & 0.128 & 0.1 .36 \\
\hline $\mathrm{MgO}$ & 8.29 & 8.44 & 8.81 & 8.61 & 9.39 & 5.48 & 8.94 & 8.43 \\
\hline $\mathrm{CaO}$ & 10.07 & 10.35 & 11.65 & 11.58 & 9.49 & 10.8 & 9.94 & 9.96 \\
\hline $\mathrm{Na}_{2} \mathrm{O}$ & 3.21 & 3.28 & 2.87 & 2.94 & 3.4 & 3.56 & 3.22 & 3.38 \\
\hline $\mathrm{K}_{2} \mathrm{O}$ & 0.317 & 0.305 & 0.167 & 0.085 & 0.677 & 0.62 & 0.404 & 0.389 \\
\hline Total & 97.65 & 100.37 & 99.34 & 99,86 & 100.75 & 99.72 & 99.95 & 99.71 \\
\hline $\mathrm{Sr}$ & 125 & 1.32 & 95 & 91 & 152 & 151 & 126 & 135 \\
\hline Ba & 57.7 & 62.2 & 18.2 & 9.8 & 97.5 & 84.6 & 74.7 & 58.9 \\
\hline $\mathrm{FeO}^{*}$ & 7.03 & 7.18 & 7.70 & 8.03 & 7.7 & 5.91 & 6.97 & 7.68 \\
\hline Group & 2 & 2 & 1 & 1 & 2 & 2 & 2 & 2 \\
\hline
\end{tabular}

shallower than that of the dividing line (i.e., they have very limited $\mathrm{Fe}$-enrichment). The very limited range of Group 1 basalts appears to have a steeper trend than do Group 2 and Group 5 glasses. Even this trend is, however, not steeper than the dividing line.

Figure 9 also shows the fields of samples from the Ecuador RiftInca Transform and the East Galapagos Rift (Fornari et al., 1983). The most magnesian samples in the former field fall near the Group 1 glasses but the AFM trend is much steeper and continued to extreme Fe-enrichment by the East Galapagos Rift glasses.

Figure $10 \mathrm{~A}$ shows the variation of $\mathrm{FeO} * / \mathrm{MgO}$ with $\mathrm{SiO}_{2}$ content of glasses from Site 862. All samples, except one Group 4 glass, have $\mathrm{FeO} * / \mathrm{MgO}$ below the tholeiite/calc-alkaline discrimination line. Group 1 samples exhibit a slight $\mathrm{Fe}$-enrichment as $\mathrm{SiO}_{2}$ increases but Group 2 and Group 5 glasses have essentially constant $\mathrm{FeO} / \mathrm{MgO}$.
These relations are entirely consistent with relations on the AFM diagram (Fig. 9).

Figure 10B compares the data for Group 1,2, and 5 glasses with those for samples from Ecuador Rift/Inca Transform and from the East Galapagos Rift. Samples from the former area do straddle the tholeiite/calc-alkaline divide at low $\mathrm{SiO}_{2}$ but move to higher $\mathrm{FeO} * / \mathrm{MgO}$ as $\mathrm{SiO}_{2}$ rises. The East Galapagos Rift glasses all lie at higher $\mathrm{FeO} * / \mathrm{MgO}$ than the dividing line and $\mathrm{FeO} * / \mathrm{MgO}$ increases as $\mathrm{SiO}_{2}$ rises. In contrast, the Site 862 glasses define a trend of no Fe-enrichment with silica increase.

\section{Group 2 Basalts}

Major-element variations of Group 2 glasses differ in several important particulars from those typical of N-type MORB. At a given 

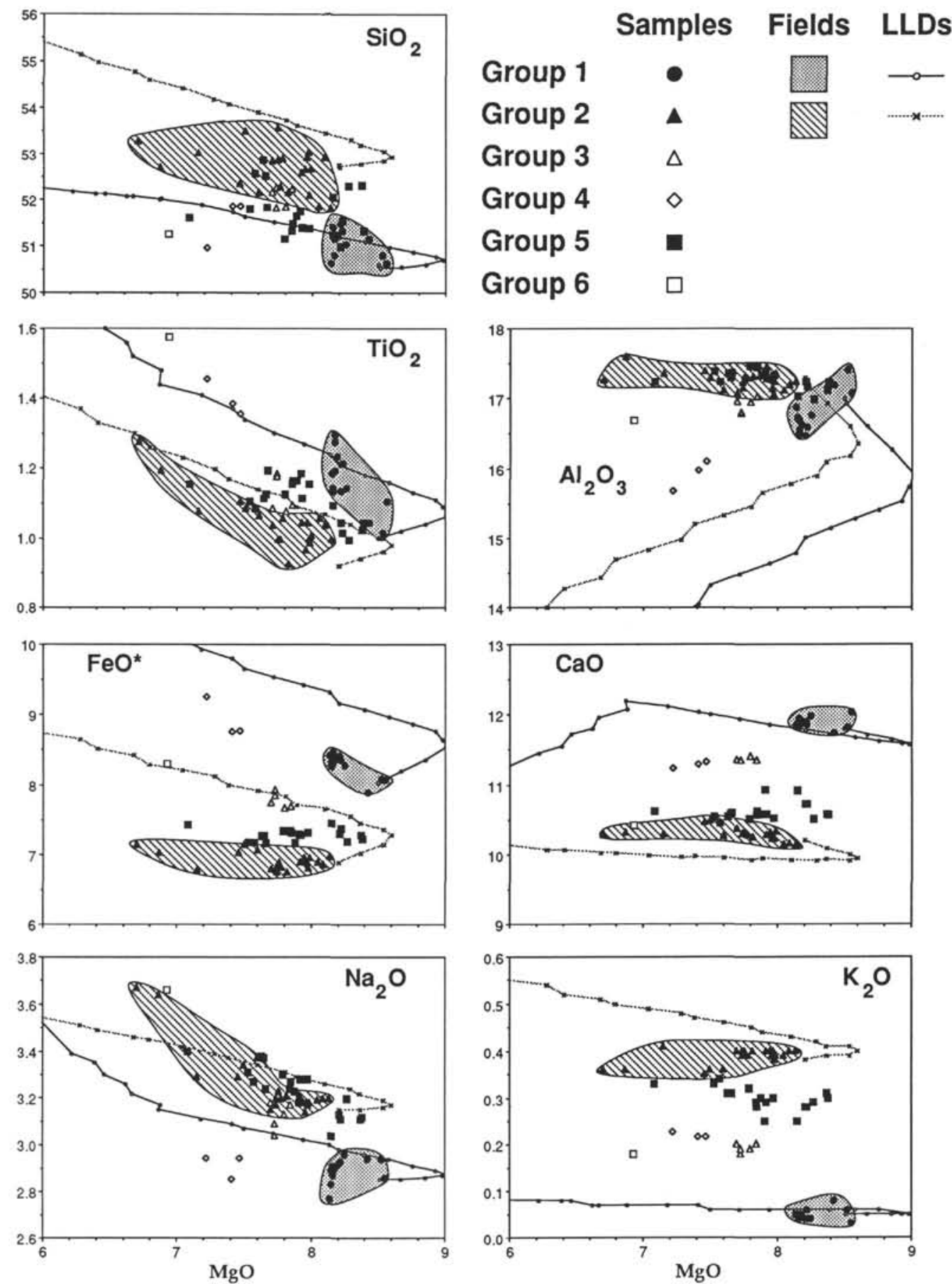

Figure 4. $\mathrm{MgO}$ variation diagrams for major oxide compositions observed in the glasses analyzed by electron microprobe. Six of the seven groups of data are plotted, along with three liquid lines of descent (LLDs) for estimated parental magmas for Groups 1 and 2. Shaded areas for Groups 1,2, and 5 glass compositions are also shown. All values are in weight percent (wt \%).

$\mathrm{MgO}$ content, Group 2 glasses have higher $\mathrm{SiO}_{2}$ and $\mathrm{K}_{2} \mathrm{O}$ and lower $\mathrm{FeO}^{*}$ and $\mathrm{CaO}$ than $\mathrm{N}$-type MORBs. (Compare Fig. 4 with Bence et al., 1979.) Group 2 glasses show a slight increase in $\mathrm{Al}_{2} \mathrm{O}_{3}$ as $\mathrm{MgO}$ falls (whereas $\mathrm{Al}_{2} \mathrm{O}_{3}$ decreases as $\mathrm{MgO}$ decreases in MORB) and no Fe-enrichment (Figs. 9 and 10). These characteristics are more like those of a calc-alkaline suite than of a MORB (tholeiitic) suite.

Figure 11 is a spidergram for one Group 1 and three Group 2 basalts compared with the N-type and E-type MORB of Sun and McDonough (1989). Data are from this paper and from Behrmann, Lewis, Musgrave, et al. (1992). The three Group 2 samples have very similar trace-element-enrichment patterns. These are generally flat at the right-hand side of the spidergram but relatively more enriched in the more incompatible elements. That part of the diagram is very irregular. $\mathrm{Pb}$ and $\mathrm{K}$ are approximately as enriched over primordial mantle as is $\mathrm{Rb}$. In particular, $\mathrm{Pb}$ is enriched over LREE; $\mathrm{Nb}$ and, to a lesser extent, $\mathrm{Ba}$ are depleted relative to $\mathrm{K}$ and $\mathrm{Rb}$.

The pattern of the E-type MORB plotted on Figure 11 (from Sun and McDonough, 1989) is broadly similar to the Group 2 basalts insofar as contents at the left-side are 1.5 to 2 times the contents at the right side. There are, however, several differences. The Group 2 
basalts are much more enriched in $\mathrm{K}$ and Rb than E-type MORBs. The Group 2 basalts have a positive $\mathrm{Pb}$ spike whereas the E-type MORB has a negative $\mathrm{Pb}$ spike. (The negative spike in MORBs on Figure 11 results from using a P.M. value of $0.185 \mathrm{ppm}$.) Group 2 basalts have negative $\mathrm{Nb}$ spikes; E-type MORBs have slight positive $\mathrm{Nb}$ spikes.

Group 2 basalts are enriched in $\mathrm{Pb}$ and depleted in $\mathrm{Nb}$. $\mathrm{Ce} / \mathrm{Pb}$ of MORB and OIB is essentially constant near 25, and MORB and OIB have $\mathrm{K} / \mathrm{Nb} \cong 260$ and $\mathrm{Nb} / \mathrm{Pb} \cong 7.8$ (Sun McDonough, 1989). Group 2 basalts have values of these ratios of $4-5,1120-1650$, and $0.8-1.1$, respectively. This must reflect addition of a component enriched in $\mathrm{K}$ and $\mathrm{Pb}$ releative to $\mathrm{Nb}$ to the mantle source of these liquids. Furthermore, because $\mathrm{K} / \mathrm{Pb}$ of MORB and OIB is near 2000 and the Group 2 basalts have $\mathrm{K} / \mathrm{Pb}$ from 1170 to 1650 , the added material was enriched in $\mathrm{Pb}$ more than it was enriched in $\mathrm{K}$.

Group 2 basalts are also depleted in titanium and phosphorous. This set of characteristics is indicative of addition of a subducted sediment-like component to the mantle. Only limited amounts of sediment need be added to the mantle to produce such trace-element ratios. The average pelagic clay of Taylor and McLennan (their table $2.3 ; 1985$ ) has $30 \mathrm{ppm} \mathrm{Pb}$ and $\mathrm{Ce} / \mathrm{Pb}=2.7$, and many pelagic sediments have much lower $\mathrm{Ce} / \mathrm{Pb}$. The pelagic clay of Taylor and McLennan also has $\mathrm{K} / \mathrm{Nb} \cong 1800$ and $\mathrm{Nb} / \mathrm{Pb} \cong 0.5$. One major problem with this scenario is the depleted Ba signature in Group 2 glasses. The average pelagic clay of Taylor and McLennan (1985) has 2300 ppm Ba so that mantle contaminated with sediment has much greater ratios of $\mathrm{Ba}$ to other incompatible elements than are exhibited by the glasses of Group 2. Figure 12 shows $\mathrm{Ba} / \mathrm{Zr}-\mathrm{Ce} / \mathrm{Zr}$ relations of Group 1 and 2 basalts superimposed on the fields of Saunders and Tarney (1991). They used these relations to discriminate between MORBs, back-arc basalts, and island arc basalts. Addition of a subducted sediment component shifts the mantle to higher values of both $\mathrm{Ba} / \mathrm{Zr}$ and $\mathrm{Ce} / \mathrm{Zr}$ but $\mathrm{Ba} / \mathrm{Zr}$ increases more rapidly because sediment has such high Ba contents. N-type MORBs have low values of both $\mathrm{Ce} / \mathrm{Zr}$ and $\mathrm{Ba} / \mathrm{Zr}$-near those of primitive mantle $(0.1,0.09 ; \mathrm{Ce} / \mathrm{Bat} 1)$. Arc basalts have a wide range of compositions that overlap with $\mathrm{N}$-type MORBs at the low end of their $\mathrm{Ce} / \mathrm{Zr}$ but are displaced to higher $\mathrm{Ba} / \mathrm{Zr}(>1)$. E-type MORBs define a trend from near the high- $\mathrm{Ba} / \mathrm{Zr}$ end of the $\mathrm{N}$-type MORB toward the OIB field at higher $\mathrm{Ba} / \mathrm{Zr}$ and $\mathrm{Ce} / \mathrm{Zr}$.

The Group 2 basalts define a trend from near the N-type MORB field to higher $\mathrm{Ba} / \mathrm{Zr}$ at essentially identical $\mathrm{Ce} / \mathrm{Zr}$. These samples do not overlap with the arc fields denoted by Saunders and Tarney (1991). Displacement of Group 2 basalts from the N-type MORB field is, however, toward the arc fields.

Group 2 basalts have $\mathrm{Sr}-\mathrm{Nd}$ isotopic compositions that do not lie in the same field as EPR basalts. They are shifted toward the $\mathrm{Sr}-\mathrm{Nd}$ compositions of basalts and andesites from the nearby Austral Andes and South Volcanic Zone of the South American mainland (e.g., Stern et al., 1984a, give the average ${ }^{87} \mathrm{Sr} /{ }^{86} \mathrm{Sr}$ and ${ }^{143} \mathrm{Nd} /{ }^{144} \mathrm{Nd}$ of Mt. Burney in the Austral Andes as 0.70416, and 0.512754, respectively; and Stern et al., 1984b, give average ratios from three Southern Volcanic Zone volcanoes as 0.7050 , and 0.51260 , respectively).

The $\mathrm{Sr}-\mathrm{Nd}$ isotopic compositions of the Group 2 basalts also lie in the field defined by five samples of the Taitao ophiolite (Kaeding et al., 1990). Isotopic data for the ophiolite define a trend from values within the EPR field toward the field defined by the felsic Tres Montes intrusive suite.

$\mathrm{Pb}$ isotopic compositions of the Group 2 basalts also differ from those of MORB as shown by Figure 7A. They have much higher ${ }^{207} \mathrm{~Pb} /{ }^{204} \mathrm{~Pb}$ than Nazca Plate basalts (Unruh and Tatsumoto, 1976) but fall in the fields defined by the Southern Volcanic Zone, and by sediments of the Nazca Plate. Similar relations are shown by ${ }^{206} \mathrm{~Pb} /{ }^{204} \mathrm{~Pb}-{ }^{208} \mathrm{~Pb} /{ }^{204} \mathrm{~Pb}$ systematics.

Some aspects of the Group 2 basalts' chemistry are consistent only with production of the primary magmas from a source containing a subducted sediment-like component. The strongest evidence for such a component is provided by the relative enrichments in $\mathrm{Pb}$ and the alkalis and depletion in $\mathrm{Nb}$ and by the $\mathrm{Pb}$ isotopic ratios. Furthermore,
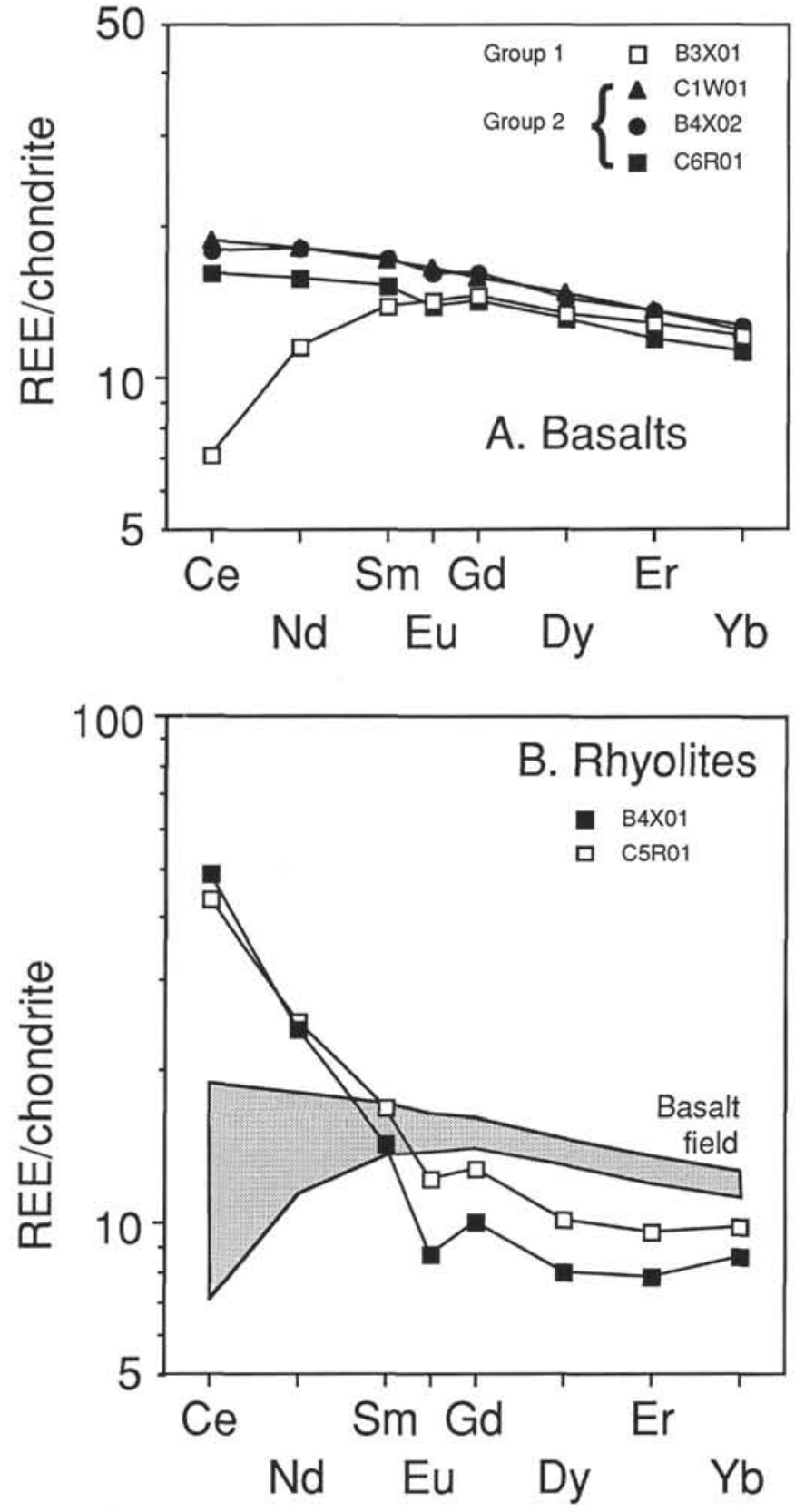

Figure 5. A. Chondrite-normalized REE patterns for four Leg 141 basaltic glass samples. Samples keyed as follows: Group 1 $=3 \mathrm{X} 1$ (Sample 141-862B-3X-1, 95-100 cm); Group 2 = $1 \mathrm{~W} 1$ (Sample 141-862C-W-1, 37-38 cm), 4X2 (Sample 141-862B-4X-2, 40-45 cm), 6RI (Sample 141-862C-6R-1, 25-30 $\mathrm{cm})$. B. Chondrite-normalized REE patterns for two Leg 141 rhyolite samples. Samples keyed as follows: $4 \mathrm{X} 1=$ Sample 141-862B-4X-01, $21-28 \mathrm{~cm} ; 5 \mathrm{R} 1$ $=$ Sample 141-862C-5R-01, 11-18 cm.

the trend of Group 2 glasses is calc-alkaline rather than tholeiitic. The most problematic aspect of interpreting Group 2 basalts as calcalkaline is their low Ba contents. Such an interpretation is, however, the best fit to the entire dataset.

\section{Group 1 Basalts}

Interpretation of the Group 1 basalts as N-type MORBs appears to be straightforward. As discussed above, the rocks have a majorelement trend very similar to those defined by other MORBs. The one sample analyzed for trace-elements and isotopes has a trace-element- 
Figure 6. Variations of $\mathrm{Sr}$ and $\mathrm{Nd}$ isotopic ratios of one Group I basalt, three Group 2 basalts, and two rhyolites compared with fields of Mid-Atlantic Ridge (MAR) and East Pacific Rise (EPR) MORBs. The field of Taitao ophiolite compositions is from Kaeding et al. (1990).
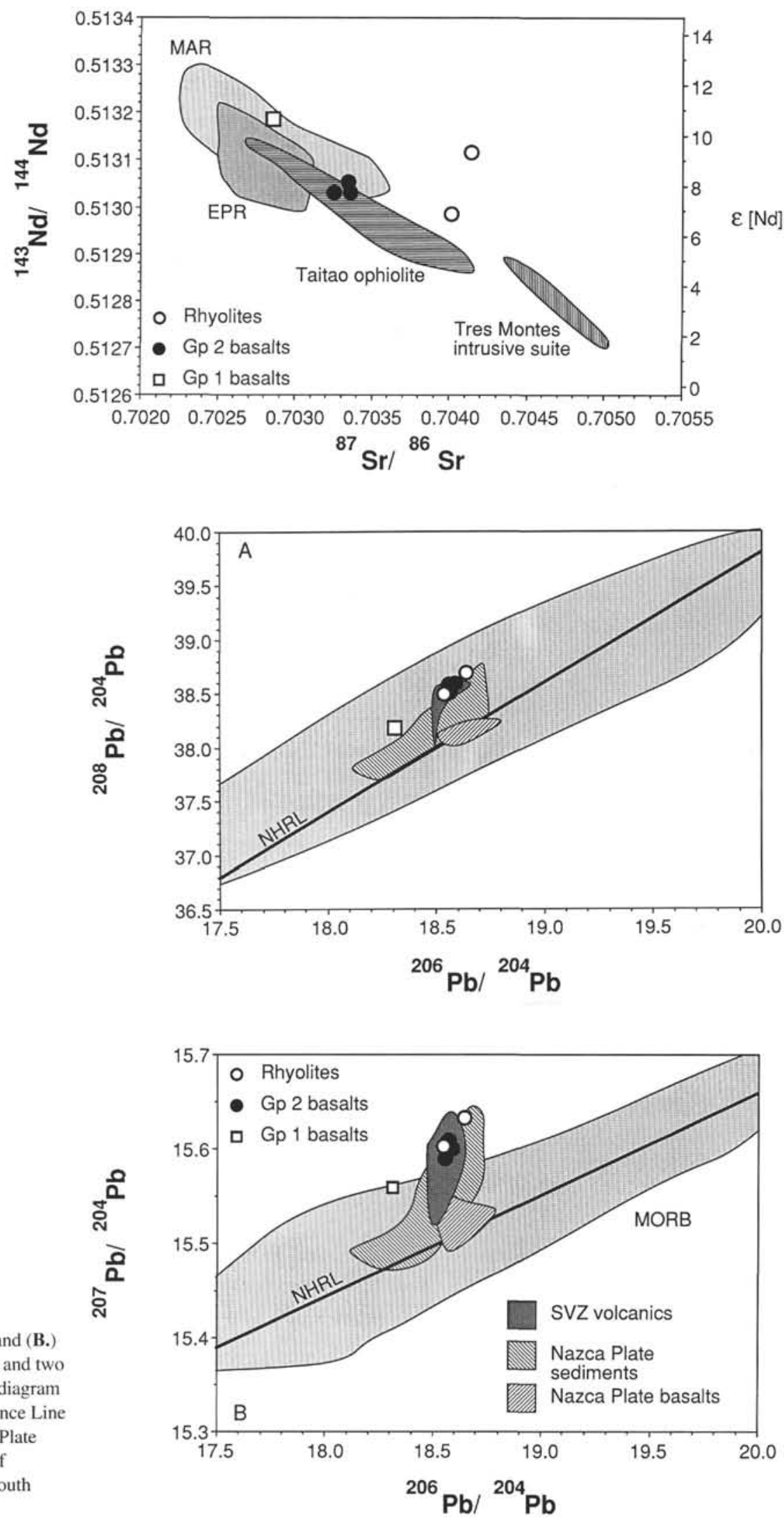

Figure 7. Variations of ${ }^{206} \mathrm{~Pb} /{ }^{204} \mathrm{~Pb}$ with (A.) ${ }^{208} \mathrm{~Pb} /{ }^{204} \mathrm{~Pb}$ and (B.) ${ }^{207} \mathrm{~Pb} /{ }^{204} \mathrm{~Pb}$ for one Group 1 basalt, three Group 2 basalts, and two rhyolites. The fields for most MORBs are shown on each diagram and are distributed about the Northern Hemisphere Reference Line (NHRL) in each case. Also shown are the fields of Nazca Plate basalts and sediments (Unruh and Tatsumoto, 1976) and of volcanic rocks of the South Volcanic Zone (SVZ) of the South American mainland. 
Table 4. REE analyses of Site 862 Taitao Ridge samples.

\begin{tabular}{|c|c|c|c|c|c|c|}
\hline Hole: & $862 \mathrm{C}$ & $862 \mathrm{C}$ & $862 \mathrm{~B}$ & $862 \mathrm{~B}$ & $862 \mathrm{~B}$ & $862 \mathrm{C}$ \\
\hline Core, section: & IW-1 & $6-1$ & $3 \mathrm{X}-1$ & $4 X-2$ & $4 X-1$ & $5 R-1$ \\
\hline \multirow[t]{2}{*}{ Rock type: } & Basalt & Basalt & Basalt & Basalt & Rhyolite & Rhyolite \\
\hline & Abs/Norm. & Abs/Norm. & Abs/Norm. & Abs/Norm. & Abs/Norm. & Abs/Norm. \\
\hline \multicolumn{7}{|l|}{ REE (ppm) } \\
\hline $\mathrm{Ce}$ & $15.2 / 18.7$ & $13.0 / 16.0$ & $5.74 / 7.06$ & $14.6 / 17.9$ & $39.5 / 48.6$ & $35.2 / 43.2$ \\
\hline $\mathrm{Nd}$ & $10.7 / 18.0$ & $9.40 / 15.7$ & $6.91 / 11.6$ & $10.8 / 18.1$ & $14.3 / 24.0$ & $14.8 / 24.8$ \\
\hline $\mathrm{Sm}$ & $3.29 / 17.1$ & $2.90 / 15.1$ & $2.65 / 13.8$ & $3.33 / 17.3$ & $2.77 / 14.4$ & $3.25 / 16.9$ \\
\hline $\mathrm{Eu}$ & $1.19 / 16.5$ & $1.00 / 13.9$ & $1.03 / 14.2$ & $1.16 / 16.1$ & $0.625 / 8.66$ & $0.882 / 12.2$ \\
\hline Gd & $4.06 / 15.7$ & $3.67 / 14.2$ & $3.74 / 14.5$ & $4.16 / 16.1$ & $2.61 / 10.08$ & $3.31 / 12.8$ \\
\hline Dy & $4.76 / 14.7$ & $4.26 / 13.1$ & $4.35 / 13.4$ & $4.64 / 14.3$ & $2.61 / 8.04$ & $3.32 / 10.2$ \\
\hline Er & $2.88 / 13.5$ & $2.56 / 12.0$ & $2.74 / 12.8$ & $2.87 / 13.5$ & $1.67 / 7.86$ & $2.06 / 9.65$ \\
\hline $\mathrm{Yb}$ & $2.56 / 12.3$ & $2.35 / 11.3$ & $2.51 / 12.1$ & $2.63 / 12.7$ & $1.78 / 8.56$ & $2.05 / 9.83$ \\
\hline
\end{tabular}

Table 5. Sr, Nd, and $\mathrm{Pb}$ isotopic compositions for Site 862 Taitao Ridge samples.

\begin{tabular}{lllcccc}
\hline $\begin{array}{c}\text { Hole, core, } \\
\text { section }\end{array}$ & ${ }^{87} \mathrm{Sr} /{ }^{86} \mathrm{Sr}$ & ${ }^{143} \mathrm{Nd} /{ }^{144} \mathrm{Nd}$ & $\mathrm{Pb}(\mathrm{ppm})$ & ${ }^{206} \mathrm{~Pb} /{ }^{204} \mathrm{~Pb}$ & ${ }^{207} \mathrm{~Pb} /{ }^{204} \mathrm{~Pb}$ & ${ }^{2018} \mathrm{~Pb} /{ }^{204} \mathrm{~Pb}$ \\
\hline $862 \mathrm{C}-1 \mathrm{~W}-1$ & $0.703355 \pm 8$ & $0.513030 \pm 7$ & 3.58 & 18.568 & 15.609 & 38.542 \\
$862 \mathrm{C}-6 \mathrm{R}-1$ & $0.703256 \pm 12$ & $0.513031 \pm 7$ & 2.86 & 18.555 & 15.590 & 38.513 \\
$862 \mathrm{~B}-3 \mathrm{X}-1$ & $0.702863 \pm 9$ & $0.513186 \pm 6$ & 0.756 & 18.314 & 15.560 & 38.171 \\
$862 \mathrm{~B}-4 \mathrm{X}-2$ & $0.703345 \pm 10$ & $0.513054 \pm 8$ & 2.72 & 18.590 & 15.600 & 38.586 \\
$862 \mathrm{~B}-4 \mathrm{X}-1$ & $0.704140 \pm 9$ & $0.513115 \pm 9$ & 3.60 & 18.549 & 15.603 & 38.503 \\
$862 \mathrm{C}-5 \mathrm{R}-1$ & $0.704015 \pm 8$ & $0.512985 \pm 10$ & 15.4 & 18.642 & 15.633 & 38.695 \\
& & & & & &
\end{tabular}

enrichment pattern very similar to that of many MORB (Fig. 11). That pattern shows a gradual decrease from right to left with few spikes except for the enrichment in Rb. This anomaly is unexplained but may reflect some slight hydrothermal alteration of this Rb-poor sample.

The Group 1 basalt has isotopic compositions that are broadly consistent with many MORBs, particularly $\mathrm{Sr}-\mathrm{Nd}$ isotopic compositions. The Group 1 sample does not have $\mathrm{Pb}$ isotopic compositions identical to those of Nazca Plate basalts. It has lower ${ }^{206} \mathrm{~Pb} /{ }^{204} \mathrm{~Pb}$ but higher ${ }^{207} \mathrm{~Pb} /{ }^{204} \mathrm{~Pb}$ than the data of Unruh and Tatsumoto (1976). It also has higher ${ }^{208} \mathrm{~Pb} /{ }^{204} \mathrm{~Pb}$ than the Nazca Plate basalts, which lie near the NHRL on the ${ }^{206} \mathrm{~Pb} /{ }^{204} \mathrm{~Pb}-{ }^{208} \mathrm{~Pb} /{ }^{204} \mathrm{~Pb}$ diagram (Fig. 7b).

Many chemical characteristics of the Group 1 basalts are closely similar to those of $\mathrm{N}$-type MORBs. They do, however, deviate in several particulars. We discussed earlier the lack of strong Fe-enrichment in Group 1 glasses and the fact that $\mathrm{AFM}$ and $\mathrm{FeO} * \mathrm{MgO}-\mathrm{SiO}_{2}$ relations follow a calc-alkaline trend but are marginal to a tholeiitic trend. The $\mathrm{Pb}$ content and $\mathrm{Pb}$ isotopic ratios of the Group 1 basalt also differ from those of most MORBs and those of the Nazca plate basalts. Both of these deviations from commonly-observed behavior of MORB may be the result of introduction of small amounts of subducted sediment into the source of Group 1 basalts. The low $\mathrm{Pb}$ content of the mantle and its very high content, even with respect to other highly incompatible elements, in sediments means that $\mathrm{Pb}$ contents and isotopic ratios are highly sensitive to contamination by sedimentary rocks. Addition of an oxidized hydrous sediment to the mantle, even in small amounts, also can result in production of magmas that evolve differently from magmas formed from uncontaminated mantle.

We earlier defined Group 5 glasses on the basis of their major element chemistry as being intermediate between Group 1 and Group 2 glasses. As Group 5 glasses are known only from glass shards, we have no trace-element or isotopic composition data for these rocks. Group 5 liquids define a trend on an AFM diagram between the trends of Group 2 and Group 1 liquids. The three groups also form a single trend on an $\mathrm{SiO}_{2}-\mathrm{FeO} / \mathrm{MgO}$ diagram (Fig. 10). The available data suggest that there is a continuum from $\mathrm{N}$-type MORB to arc basalts in the samples from the Taitao Ridge. Presumably this reflects the amount of sediment incorporated in the source of each magma batch produced during juxtaposition of the ridge and the trench.
Table 6. Calculated $1 \mathrm{~atm}$ liquid lines of descent for possible Leg 141 parental magmas.

\begin{tabular}{|c|c|c|c|c|c|}
\hline & \multicolumn{5}{|c|}{ Group I } \\
\hline & $\begin{array}{l}\text { Parental } \\
\text { Magma }\end{array}$ & $\begin{array}{l}\text { After } 4.2 \% \\
\text { Xiln. }\end{array}$ & $\begin{array}{l}\text { After } 16.2 \% \\
\text { Xtln. }{ }^{\text {. }}\end{array}$ & $\begin{array}{l}\text { After } 30.2 \% \\
\quad \text { Xtln. }\end{array}$ & $\begin{array}{l}\text { After } 46.2 \% \\
\text { Xtin. }\end{array}$ \\
\hline \multicolumn{6}{|c|}{ Major elements (wt $\%$ ) } \\
\hline $\mathrm{SiO}_{2}$ & 50.60 & 50.59 & 51.08 & 51.88 & 52.18 \\
\hline $\mathrm{TiO}_{2}^{-}$ & 1.00 & 1.04 & 1.18 & 1.41 & 1.75 \\
\hline $\mathrm{Al}_{2} \mathrm{O}_{3}$ & 17.00 & 16.27 & 15.15 & 13.87 & 13.09 \\
\hline $\mathrm{FeO}^{*}$ & 8.00 & 8.36 & 9.07 & 9.92 & 11.55 \\
\hline $\mathrm{MnO}$ & 0.10 & 0.10 & 0.11 & 0.12 & 0.14 \\
\hline $\mathrm{MgO}$ & 8.50 & 8.85 & 8.40 & 7.18 & 6.14 \\
\hline $\mathrm{CaO}$ & 11.80 & 11.64 & 11.72 & 12.12 & 1.26 \\
\hline $\mathrm{Na}_{2} \mathrm{O}$ & 2.85 & 2.86 & 2.96 & 3.11 & 3.43 \\
\hline $\mathrm{K}, \mathrm{O}$ & 0.05 & 0.05 & 0.06 & 0.07 & 0.08 \\
\hline $\mathrm{P}_{2} \mathrm{O}_{5}$ & 0.10 & 0.10 & 0.12 & 0.14 & 0.18 \\
\hline \multirow[t]{4}{*}{ Total } & 100.00 & 99.86 & 99.85 & 99.82 & 99.80 \\
\hline & \multicolumn{5}{|c|}{ Group 2} \\
\hline & Parental & After $4.2 \%$ & After $16.2 \%$ & After $38.2 \%$ & After $54.2 \%$ \\
\hline & Magma & $X t \ln .^{c}$ & XtIn! & $\mathrm{Xtln} \mathrm{g}^{\mathrm{g}}$ & Xtln. ${ }^{h}$ \\
\hline \multicolumn{6}{|c|}{ Major elements (wt\%) } \\
\hline $\mathrm{SiO}_{2}$ & 52.75 & 52.84 & 53.60 & 55.61 & 56.69 \\
\hline $\mathrm{TiO}_{2}^{2}$ & 0.92 & 0.96 & 1.09 & 1.45 & 1.87 \\
\hline $\mathrm{Al}_{2} \mathrm{O}_{3}$ & 17.30 & 16.61 & 15.66 & 13.64 & 12.89 \\
\hline $\mathrm{FeO}^{-3}$ & 6.90 & 7.15 & 7.71 & 8.82 & 10.38 \\
\hline $\mathrm{MnO}$ & 0.10 & 0.10 & 0.11 & 0.13 & 0.14 \\
\hline $\mathrm{MgO}$ & 8.20 & 8.54 & 7.89 & 5.69 & 4.42 \\
\hline $\mathrm{CaO}$ & 10.20 & 10.00 & 9.94 & 10.19 & 8.54 \\
\hline $\mathrm{Na}_{2} \mathrm{O}$ & 3.15 & 3.16 & 3.29 & 3.57 & 3.94 \\
\hline $\mathrm{K}_{2} \mathrm{O}$ & 0.38 & 0.39 & 0.44 & 0.57 & 0.74 \\
\hline $\mathrm{P}_{2} \mathrm{O}_{5}$ & 0.10 & 0.10 & 0.12 & 0.16 & 0.21 \\
\hline Total & 100.00 & & & & \\
\hline
\end{tabular}

${ }^{4} 4.2 \%$ crystallization of $\mathrm{An}_{75-76}$ (onset of olivine crystallization immediately follows). ${ }^{b}$ an additional $8.8 \%$ crystallization of $\mathrm{An}_{73-75}$ and $3.2 \%$ crystallization of $\mathrm{Fo}_{87-88}$.

$c$ an additional $9.2 \%$ crystallization of $\mathrm{An}_{69-73}$ and $4.8 \%$ crystallization of Fo ${ }_{84-87}$ (onset of CPX crystallization immediately follows).

${ }^{d}$ an additional $8.0 \%$ crystallization of $\mathrm{An}_{63-68}, 1.5 \%$ crystallization of $\mathrm{Fo}_{80-84}$. and $6.5 \%$ crystallization of CPX.

${ }^{e} 4.2 \%$ crystallization of $\mathrm{An}_{73-74}$ (onset of olivine crystallization immediately follows).

$r_{\text {an }}$ additional $8.5 \%$ crystallization of $\mathrm{An}_{71-73}$ and $3.5 \%$ crystallization of Fo88-9\%

${ }^{2}$ an additional $16.0 \%$ crystallization of $\mathrm{An}_{62-70}$ and $6.0 \%$ crystallization of $\mathrm{Fo}_{83}-88$ (onset of CPX crystallization immediately follows).

${ }^{h}$ an additional $8.0 \%$ crystallization of $\mathrm{An}_{53}-62,0.8 \%$ crystallization of Fo $77-83$, and $7.2 \%$ crystallization of CPX. 

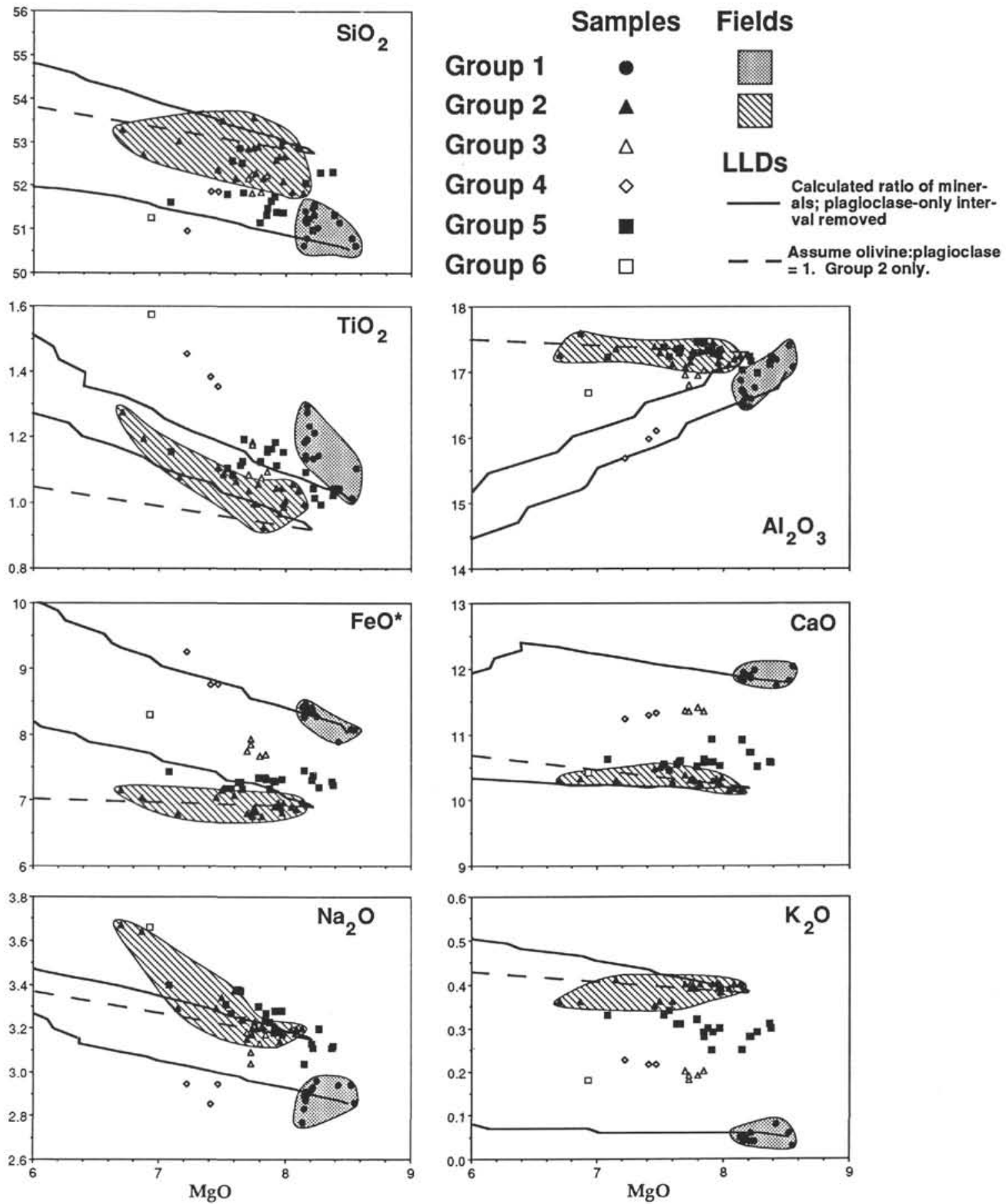

Figure 8. $\mathrm{MgO}$ variation diagrams of major oxides showing approximated liquid lines of descent for Group 1 and 2 glasses without an early plagioclase-only phase of crystallization. Also shown is the alternative non-cotectic liquid of descent for a 50:50 olivine-plagioclase crystallization sequence. See text for further discussion. All values are in weight percent $(\mathrm{wt} \%)$.

\section{Petrogenesis of Silicic Lavas}

On the basis of prior studies of silicic magmatism at mid-ocean ridges and the data on the Site 862 samples, four models for the origin of the Site 862 rhyolites are evaluated. These models include the following: (1) the rhyolites formed by extreme differentiation of basaltic magmas; (2) the rhyolites were produced by liquid immiscibility with basaltic magmas; (3) the rhyolites result from anatexis of altered oceanic crust; and (4) the rhyolites were melts of material that was sedimentary or of continental crust origin.
The $\mathrm{Nd}, \mathrm{Sr}$, and $\mathrm{Pb}$ isotopic differences between the rhyolites and Group 1 basalts clearly preclude any genetic relationship between these rocks by differentiation, liquid immiscibility, or partial melting. It is also possible to preclude any genetic relationship between the Group 2 basalts and the rhyolites by extreme differentiation or liquid immiscibility, principally because of the significantly higher ${ }^{87} \mathrm{Sr} /{ }^{86} \mathrm{Sr}$ in the rhyolites.

The rhyolites plausibly formed by partial melting of altered oceanic crust similar to the Group 2 basalts. Isotopically, the only major difference between the Group 2 basalts and the rhyolites is the higher 
Table 7. Non-cotectic crystallization of olivine in Group 2 parent.

\begin{tabular}{|c|c|c|c|c|c|}
\hline & Parent & Olivine & Plagioclase & Bulk & Res. liquid \\
\hline \multicolumn{6}{|c|}{ Major element (wt\%) } \\
\hline $\mathrm{SiO}_{2}$ & 52.75 & 40.38 & 50.44 & 45.41 & 53.57 \\
\hline $\mathrm{TiO}_{2}^{-}$ & 0.92 & 0.06 & 0.00 & 0.03 & 1.02 \\
\hline $\mathrm{Al}_{2} \overline{\mathrm{O}}_{3}$ & 17.30 & 0.00 & 31.78 & 15.89 & 17.46 \\
\hline $\mathrm{FeO}$ & 6.90 & 11.86 & 0.37 & 6.12 & 6.99 \\
\hline $\mathrm{MnO}$ & 0.10 & 0.17 & 0.00 & 0.09 & 0.10 \\
\hline $\mathrm{MgO}$ & 8.20 & 47.07 & 0.31 & 23.69 & 6.48 \\
\hline $\mathrm{CaO}$ & 10.20 & 0.23 & 13.72 & 6.98 & 10.56 \\
\hline $\mathrm{Na}_{2} \mathrm{O}$ & 3.15 & 0.00 & 3,30 & 1.65 & 3.32 \\
\hline $\mathrm{K}, \mathrm{O}$ & 0.38 & 0.00 & 0.09 & 0.00 & 0.42 \\
\hline $\mathrm{P}_{2} \mathrm{O}_{5}$ & 0.10 & 0.00 & 0.00 & 0.05 & 0.11 \\
\hline Total & 100.00 & 99.77 & 100.01 & 99.89 & 100.01 \\
\hline $\mathrm{F}$ of $\mathrm{Min}$. & & 0.50 & 0.50 & 0.10 & 0.90 \\
\hline
\end{tabular}

${ }^{87} \mathrm{Sr} /{ }^{86} \mathrm{Sr}$ in the rhyolites. If oceanic crust of Group 2 composition were hydrothermally altered by interaction with seawater, the ${ }^{87} \mathrm{Sr} /{ }^{86} \mathrm{Sr}$ of the altered oceanic crust would be increased, whereas the $\mathrm{Nd}$ and $\mathrm{Pb}$ isotopic ratios would not change significantly.

Alternatively, the higher ${ }^{87} \mathrm{Sr} /{ }^{86} \mathrm{Sr}$ of the rhyolites could reflect incorporation of continental crustal material in the rhyolite sources. The similarity between $\mathrm{Pb}$ isotopic ratios of the Group 2 basalts and the rhyolites indicates that the source of the latter contained little old continental material as old crust has elevated ${ }^{207} \mathrm{~Pb} /{ }^{204} \mathrm{~Pb}$ and ${ }^{208} \mathrm{~Pb} /{ }^{204} \mathrm{~Pb}$ due to high early in the history of the crust and to the higher $\mathrm{Th} / \mathrm{U}$ of the crust.

A third possibility is that the elevated ${ }^{87} \mathrm{Sr} /{ }^{86} \mathrm{Sr}$ of the rhyolites reflects in situ growth of radiogenic Sr. Groundmass-rich rhyolites have $100 \mathrm{ppm} \mathrm{Rb}$ and 110-120 ppm Sr. An upper limit on the ${ }^{87} \mathrm{Rb} /{ }^{86} \mathrm{Sr}$ of the source of the rhyolites of 2.35 is calculated assuming that $\mathrm{Rb}$ and $\mathrm{Sr}$ were not fractionated from each other during anatexis. If the sources formed $23 \mathrm{Ma}$ ago (early Miocene), the sources had $\left({ }^{87} \mathrm{Sr} /{ }^{86} \mathrm{Sr}\right), 0.7033$. Fractionation of $\mathrm{Rb}$ from $\mathrm{Sr}$ during anatexisexpected for a feldspar-bearing residue-means that the source had lower $\mathrm{Rb} / \mathrm{Sr}$ and higher $\left({ }^{87} \mathrm{Sr} /{ }^{86} \mathrm{Sr}\right)_{i}$. In situ growth can explain some, but not all, of the difference in ${ }^{87} \mathrm{Sr} /{ }^{86} \mathrm{Sr}$ between the rhyolites and the Group 2 basalts.

Trace-element data are also suggestive of a Group 2 basalt-like source for the rhyolites. Figure 13 is a spidergram ordered in the same way as Figure 11. The field for the Group 2 basalts is shown shaded. The general pattern of the rhyolites on the left side of this diagram is similar to, although at higher contents than, the pattern for the Group 2 basalts. In particular, the rhyolites are highly enriched in $\mathrm{Rb}$ and $\mathrm{K}$, have large negative $\mathrm{Nb}$ spikes and are somewhat depleted in $\mathrm{Ba}$ relative to the alkalis. They also reflect the lesser enrichment in LREE than K exhibited by the Group 2 basalts. Sample 141-862C-5R-1, $11-18 \mathrm{~cm}$, is also highly enriched in $\mathrm{Pb}$, but Sample 141-862B-4X-1, 21-28 cm, has a similar $\mathrm{Pb}$ content to those of the Group 2 basalts. Given the otherwise similar patterns of the two rhyolites, this plausibly reflects retention of a $\mathrm{Pb}$-concentrating phase such as sulfide in the residue of Sample 141-862C-4X-1, 11-18 cm. Zirconium is enriched in the rhyolites relative to Group 2 basalts whereas $\mathrm{Ti}$ and the HREE are depleted.

The similarities between the patterns of the rhyolites and the Group 2 basalts from Rb to Ce suggests that, although ${ }^{87} \mathrm{Sr} /{ }^{86} \mathrm{Sr}$ of the rhyolite source may have been altered by hydrothermal alteration, the trace-element pattern was essentially unchanged by this alteration. This permits estimation of the amount of melting of the source from the enrichments of incompatible elements in the rhyolites over those in the basalts. $\mathrm{Rb}$ is the most concentrated from the basalts into the rhyolites requiring $10 \%$ partial melting if absolutely incompatible in the residue. $\mathrm{K}_{2} \mathrm{O}$ and $\mathrm{Ba}$ indicate $18 \%$ and $16 \%$ partial melting, requiring that small amounts of $\mathrm{K}_{2} \mathrm{O}$ and $\mathrm{Ba}$ remain in the residue $\left(0.23 \% \mathrm{~K}_{2} \mathrm{O} ; 20\right.$ ppm Ba suggesting bulk D's of 0.08 and 0.06 respectively). Felsic liquids present in amounts much less than $10 \%$ are unlikely to escape from their residues (McKenzie, 1985).

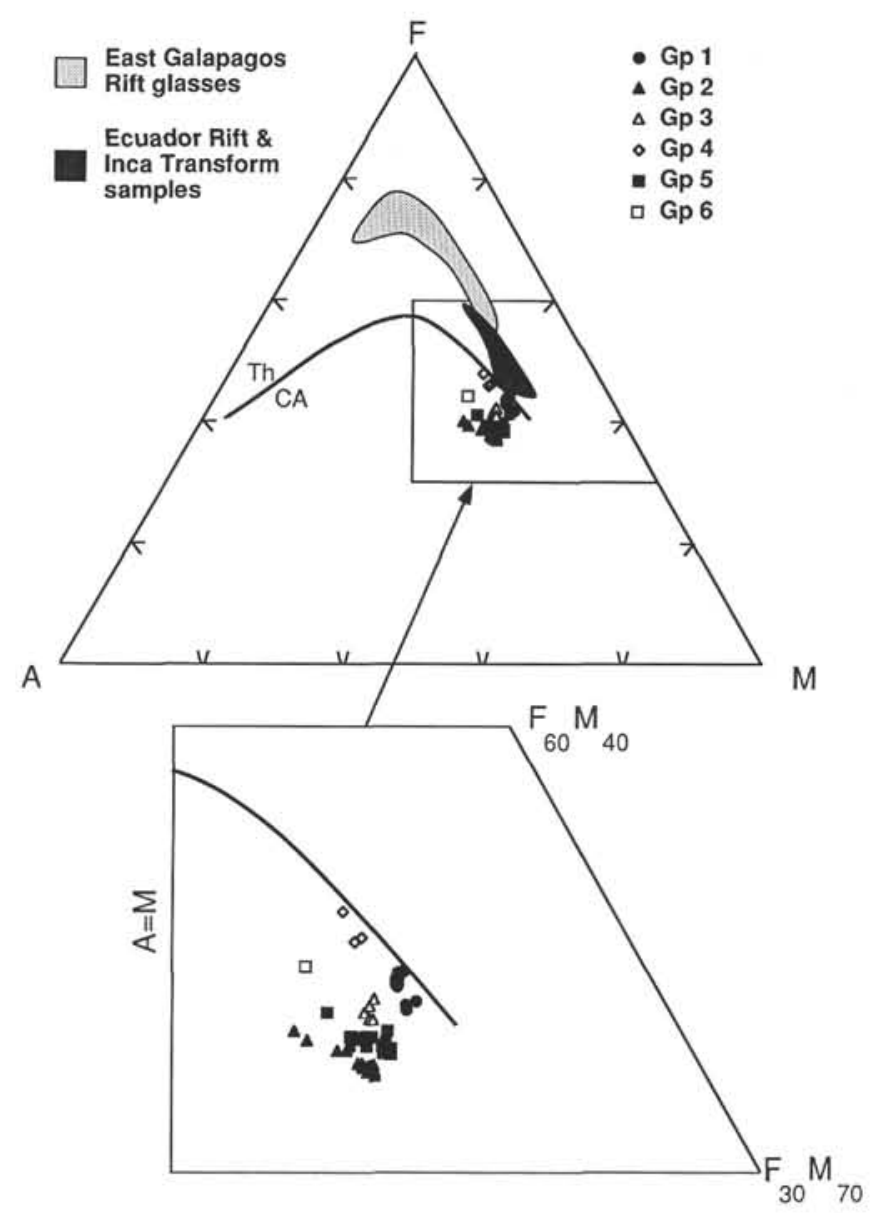

Figure 9. Conventional AFM diagram for mafic glasses analyzed by electron microprobe. $\mathrm{A}=\mathrm{Na}_{2} \mathrm{O}+\mathrm{K}_{2} \mathrm{O} ; \mathrm{F}=\mathrm{FeO}$ (total); $\mathrm{M}=\mathrm{MgO}$, all in wt $\%$. The line dividing the fields of tholeiitic (Th) and calc-alkaline (CA) suites is from Irvine and Baragar (1971). The fields of glasses and fused whole rocks from the Ecuador Rift and Inca Transform and of glasses from the East Galapagos Rift are from Fornari et al. (1983). The area containing all the Site 862 samples is enlarged in the lower part of the diagram.

The rhyolites contain corroded phenocrysts that are plausibly restitic. An altered mafic source, heated to $700 \mathrm{C}$ contains plagioclase, amphibole, biotite, and quartz. Such an assemblage produces a felsic liquid at temperatures $900^{\circ} \mathrm{C}(\mathrm{P}=0.1 \mathrm{GPa})$ to $850^{\circ} \mathrm{C}(0.7 \mathrm{GPa})$ with a residue of plagioclase and hornblende (Beard and Lofgren, 1991).

Rare-earth element patterns of the rhyolites provide constraints on the residual mineral assemblage. The similarity of the REE patterns of the rhyolites and that of average upper crust is noteworthy. Average upper crust (as reflected by average Proterozoic shale) is LREEenriched $\left(\mathrm{Ce}_{\mathrm{N}} / \mathrm{Yb}_{\mathrm{N}}=6\right.$ to 7$)$, has flat middle to heavy REE, and has a negative Eu-anomaly $\left(\mathrm{Eu} / \mathrm{Eu}^{*}=0.7\right)$. The rhyolites have lower REE contents than upper crust ( $\mathrm{Ce}_{\mathrm{N}} 40$ versus $80 ; \mathrm{Yb}_{\mathrm{N}} 7$ to 8 versus 12 ) but their REE patterns have a similar shape. The rhyolites have $\mathrm{Ce}_{\mathrm{N}} / \mathrm{Yb}_{\mathrm{N}}$ $=4.5,5.8$, flat middle to heavy REE, and $\mathrm{Eu} / \mathrm{Eu}^{*}=0.7,0.8$. This reflects a similar origin, on a small scale, of the rhyolites and the origin of upper crust (i.e., alteration of basalt, with or without sedimentation) and anatexis of the resultant rock.

Group 2 basalts have $\mathrm{Ce}_{\mathrm{N}} 15$, whereas rhyolites have $\mathrm{Ce}_{\mathrm{N}}$ of $43-$ 49; an enrichment factor of three. The HREE contents of the rhyolites are less than those of the Group 2 basalts and the rhyolites (unlike the basalts) have negative Eu-anomalies. Formation of the rhyolites by anatexis of rocks derived from Group 2 basalts requires, therefore, that minerals in the residue concentrated HREE and Eu over the liquid 


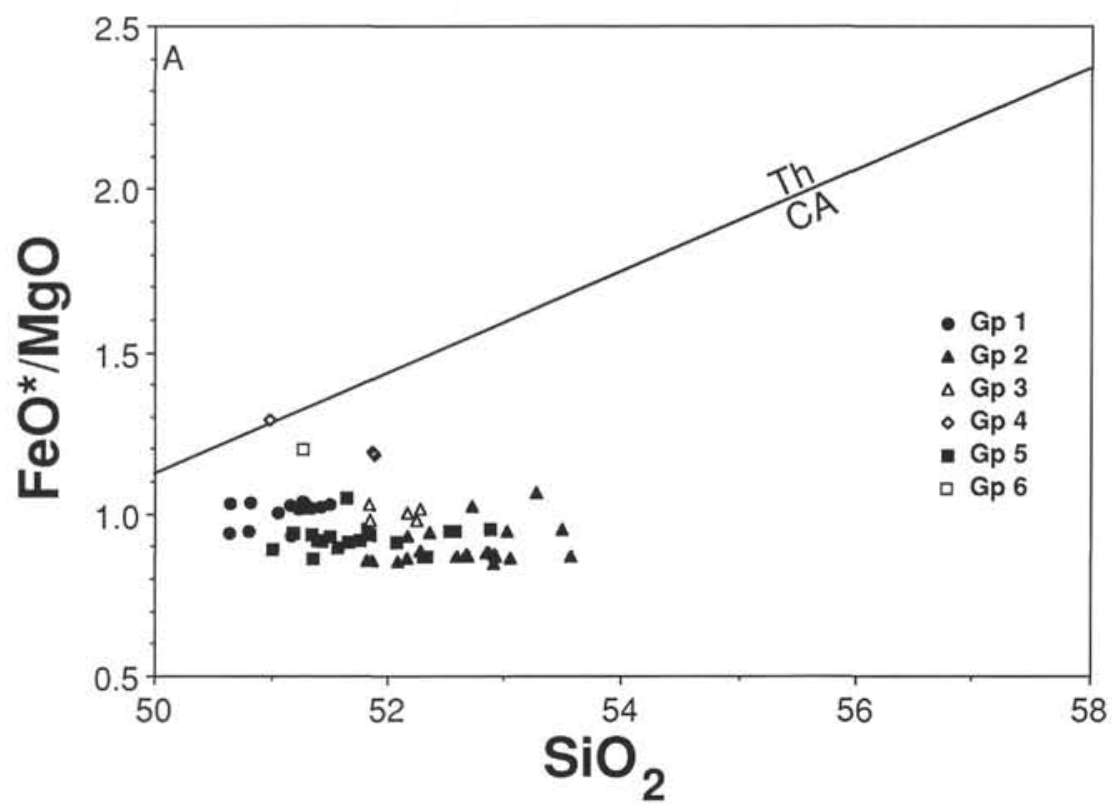

Figure 10. $\mathrm{SiO}_{2}$ against $\mathrm{FeO} * / \mathrm{MgO}$ for glasses analyzed by electron microprobe from Site 862 . A. Samples from all six groups of mafic glasses, compared with the line separating tholeiitic (Th) and calc-alkaline (CA) fields (after Miyashiro, 1974). B. Fields of Groups 1, 2, and 5 glasses compared with those of samples from the Ecuador Rift and Inca Transform and of glasses from the East Galapagos Rift. (Fields from Fornari et al., 1983.)

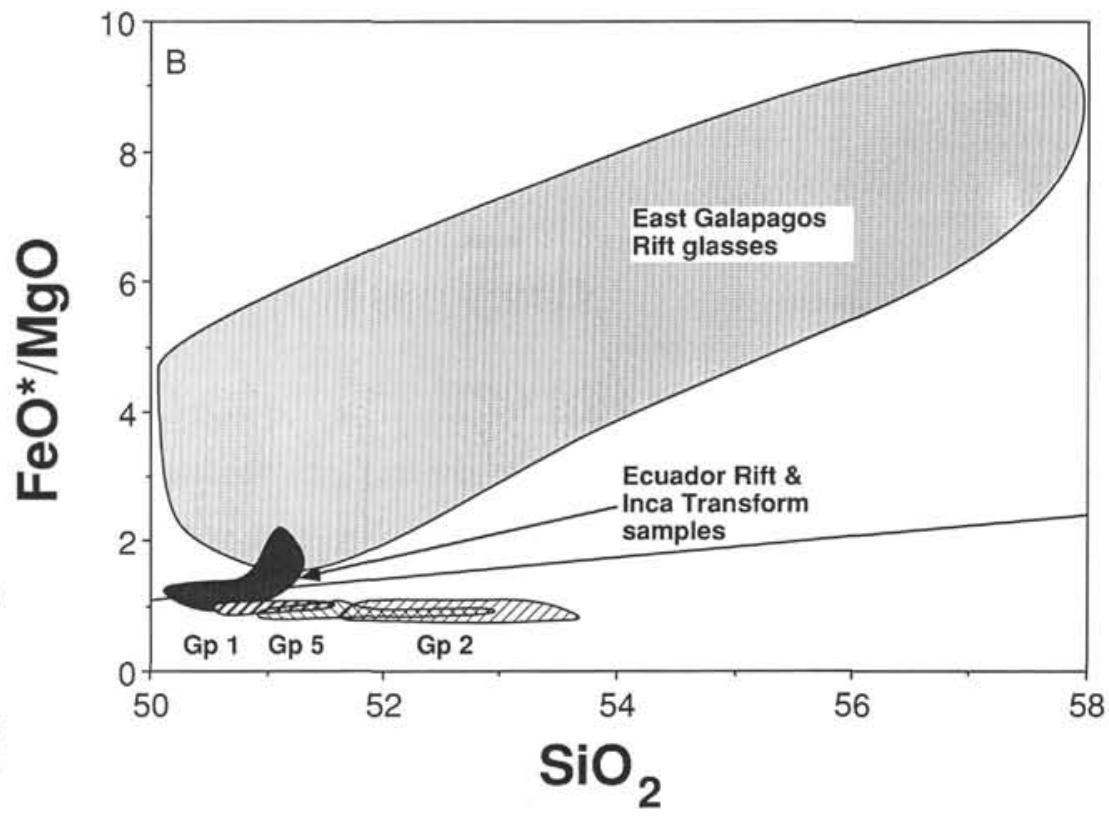

but excluded LREE. The required minerals are present as phenocrysts in the rhyolites and, if these are restite, in the residue of melting. Plagioclase and hornblende concentrate Eu and MREE/HREE over LREE with respect to felsic liquids, respectively.

We used partition coefficients for REE between plagioclase and hornblende versus dacitic liquid tabulated by Arth (1976) to calculate model liquids. The REE pattern of a model felsic liquid is compared on Figure 14 with the more LREE-enriched rhyolite and the average Group 2 basalt. This models $10 \%$ partial melting of a source similar to the average Group 2 basalt with a residue containing $75 \%$ plagioclase and $25 \%$ hornblende. Although the modeled pattern is less LREE-enriched than the rhyolite and has a larger negative Eu-anomaly, the model and the rhyolite have broadly similar REE patterns.

Three factors may explain the differences between model and data. First, assumption of a bimineralic residue is an oversimplification and minor minerals can affect the REE pattern of a coexisting liquid without much changing the major-element contents of that liquid. Second, the source could have had a somewhat different REE pattern from that used in the model either because the igneous rocks were more evolved (e.g., andesite) or because there were slight variations in REE patterns between different Group 2 basalts. Rhyolites only form from a source that contains some quartz and potassic minerals, not average crust. Finally, partition coefficients of REE are very dependent upon bulk composition in felsic magmas (compare numbers given by Arth, 1976, and Fujimaki et al., 1984, for andesiticrhyolitic rocks).

The interpreted assemblage in the residue of the felsic liquids does not place rigorous constraints on the pressure of melting. The assemblage hornblende-plagioclase-silicic liquid is stable for a mafic bulk assemblage at 0.05 to $2.3 \mathrm{GPa}$ (discussed by Burnham, 1979). Allen et al. (1975) and Allen and Boettcher (1983) show that garnet is a stable supersolidus phase in hydrous tholeiitic basaltic systems at $\mathrm{P} 1.5 \mathrm{GPa}$ at $\mathrm{T} \cong 900^{\circ} \mathrm{C}$ and slightly lower pressure in andesitic bulk compositions. Partition coefficients of REE between garnet and liquid increase markedly from LREE to HREE, particularly from Sm to Er. REE patterns of rhyolites are flat in that region. If the rhyloties 

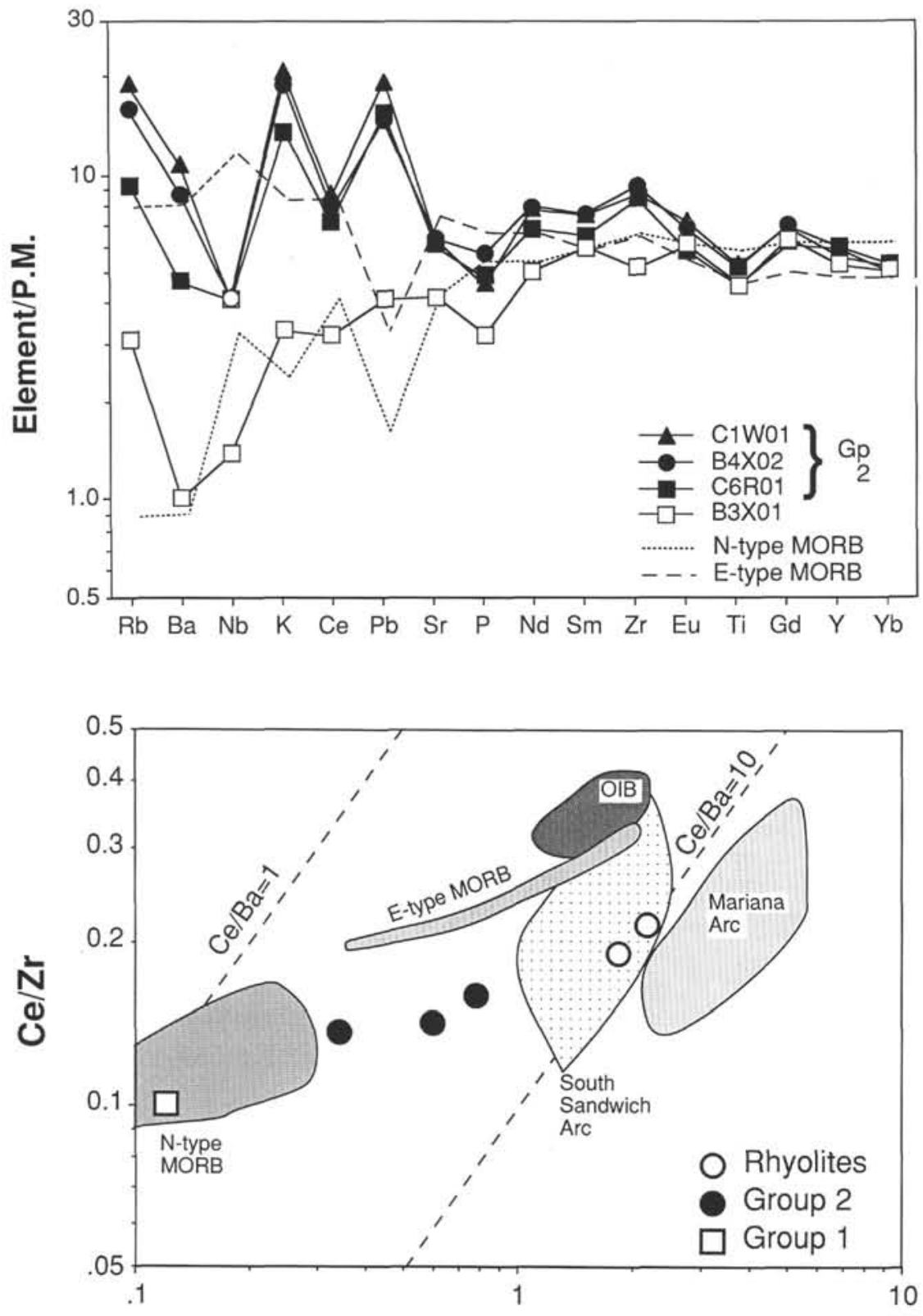

$\mathrm{Ba} / \mathrm{Zr}$
Figure 11. Enrichment patterns for trace elements in three Group 2 basalts and one Group 1 basalt. Contents are normalized to primordial mantle (P.M.) values of Sun and McDonough (1989) using $0.185 \mathrm{ppm}$ for $\mathrm{Pb}$. Data are from this paper and from Behrmann, Lewis, Musgrave, et al. (1992). The E-type and N-type MORB patterns from Sun and McDonough (1989) are reproduced for comparison. Samples keyed as in Figure 5A.
Figure $12 . \mathrm{Ba} / \mathrm{Zr}-\mathrm{Ce} / \mathrm{Zr}$ relations for one Group 1 basalt, three Group 2 basalts, and two rhyolites. Fields of $\mathrm{N}$-type MORB, E-type MORB, ocean island basalts (OIB) and two fields of island arc basalts are from Saunders and Tarney (1991). formed from a source with a flat REE pattern (e.g., a Group 2 basalt), bulk solid-liquid D's for $\mathrm{Sm}$ to $\mathrm{Yb}$ were similar and the residue contained little, if any, garnet (although it may have been in the source). The rhyolites presumably formed at P1.5 GPa.

\section{Geochemistry and Tectonics of the Taitao Ridge}

The primary magmas of Group 1 glasses probably formed in a manner similar to that inferred for other N-type MORBs: polybaric (1-3 GPa) fractional melting of the mantle produces a diverse range of primary magmas that are mixed together during ascent or within magma chambers (Johnson et al., 1990; Salters and Hart, 1989; Kinzler and Grove, 1992a, b). The Group 1 glasses plot significantly off the global array of Klein and Langmuir (1987). They have much lower $\mathrm{Fe}_{8.0}$ and $\mathrm{Na}_{8.0}$ than the array has for the depth of the Taitao Ridge (Figs. 15a and b). The Group 1 glasses may have been on the global array when they formed if the present shallow depth of the ridge is a tectonic anomaly rather than an original feature. Alternatively, the Group 1 glasses may not have been on the array. We discussed above the unusual chemistry of the Group 1 glasses, a chemistry that may have included different $\mathrm{Na}_{8.0}-\mathrm{Fe}_{8.0}$ relationships. Figure $15 \mathrm{C}$ shows the global array with the near axial depth removed as a factor so $\mathrm{Fe}_{8,0}$ is plotted against $\mathrm{Na}_{8.0}$. The Group 1 glasses lie on this global array, consistent with their dominantly MORB-like chemistry. Group 2 glasses have lower $\mathrm{Fe}_{8,0}$ than the global array and have high $\mathrm{Na}_{8,0}$. Given our interpretation of the Group 2 glasses as calcalkaline, this deviation from the global array is not surprising. The Group 5 glasses are intermediate between the Group 1 and Group 2 glasses on Figure 15.

The $\mathrm{Na}_{8.0}-\mathrm{Fe}_{8.0}$ systematics of the Group 1 glasses probably closely reflect the conditions of mantle melting of the primary liquids and were little affected by contamination in the source. The same is not likely to be true for Group 5 or Group 2 glasses. If the Group 1 glasses originally lay on the global arrays of mean axial depth against 
Figure 13. Enrichment patterns for trace elements in two rhyolites. Contents are normalized to primordial mantle (P.M.) values of Sun and McDonough (1989) as in Figure 11. The field of Group 2 basalts from Figure 11 is shown shaded. Samples keyed as in Figure 5B.
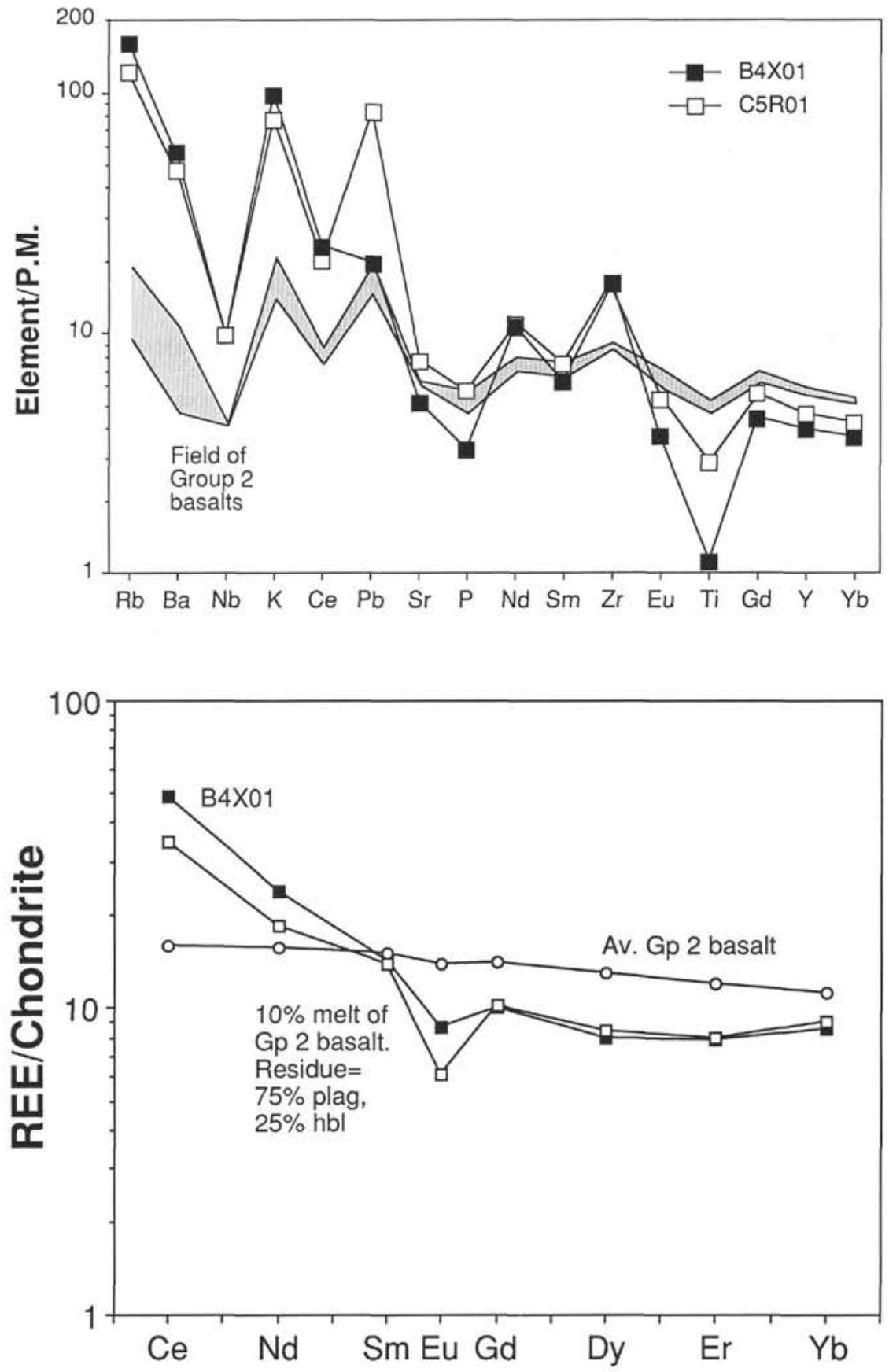

Figure 14. Interpretative REE pattern for rhyolites. The pattern for the average Group 2 basalt (from Fig. $5 \mathrm{~A}$ ) and for the more enriched rhyolite (from Fig. 5B) are shown. Also shown is the calculated pattern that one would get in a $10 \%$ melt of the average Group 2 basalt if the residue contained $75 \%$ plagioclase and $25 \%$ hornblende, using partition coefficients of Arth (1976) for dacitic liquids.
$\mathrm{Na}_{8.0}$ and $\mathrm{Fe}_{8.0}$, the Taitao Ridge must have been tectonically uplifted $2000 \mathrm{~m}$ and, possibly, as much as $4000 \mathrm{~m}$ (Fig. 15A).

\section{CONCLUSIONS}

1. Glass shards in sediments and glass rinds on basalt flows define seven compositional groups. Group 1 samples are depleted in LREE and other LILE. The compositional variations of this suite are explicable by low-pressure fractional crystallization of olivine and plagioclase in "normal" (1:2) cotectic proportions. This suite does not exhibit significant Fe-enrichment, unlike most MORB suites. The trace-element and isotopic compositions of one Group 1 basalt are broadly similar to those of $\mathrm{N}$-type MORBs. A minor enrichment in $\mathrm{Rb}$ possibly reflects post-magmatic processes. An enrichment in $\mathrm{Pb}$ $(\mathrm{Ce} / \mathrm{Pb}=7.6$ compared to 25 in MORB $)$ and the shift in ${ }^{207} \mathrm{~Pb} /{ }^{204} \mathrm{~Pb}$ and ${ }^{208} \mathrm{~Pb} /{ }^{204} \mathrm{~Pb}$ to values above the NHRL at the same ${ }^{206} \mathrm{~Pb} /{ }^{204} \mathrm{~Pb}$ are consistent with addition of a small amount of subducted sediment to part of the source of the Group 1 magmas. Addition of small amounts of oxidized and hydrated sedimentary material to the mantle may result in the magmas derived from it following a liquid line of descent nearer to those of calc-alkaline suites.

2. Group 2 samples are enriched in LREE and some LILE. The most incompatible elements are variably enriched. $\mathrm{K}, \mathrm{Rb}$, and $\mathrm{Pb}$ are highly enriched relative to LREE whereas $\mathrm{Nb}$ is depleted and $\mathrm{Ba}$ is moderately depleted. The low values of $\mathrm{Ce} / \mathrm{Pb}(4-5), \mathrm{K} / \mathrm{Pb}(1170$ $1650)$, and $\mathrm{Nb} / \mathrm{Pb}(\cong 1$ of Group 2 basalts compared to their values in most MORB $(25,2000$, and 7.8) require addition of material enriched in $\mathrm{Pb}$ and alkalis to the mantle source of the Group 2 samples.

Isotopic compositions of Group 2 samples also differ from those of many MORBs. Group 2 basalts have higher ${ }^{87} \mathrm{Sr} /{ }^{86} \mathrm{Sr}$ and lower ${ }^{143} \mathrm{Nd} /{ }^{144} \mathrm{Nd}$ than the Group 1 basalt. They lie in the field of compositions from the Taitao ophiolite (Kaeding et al., 1990). Pb isotopic 
compositions also differ from those of most MORBs and are similar to those of arc volcanoes on the South American mainland and those of sediments of the Nazca Plate.

The trend of Group 2 glasses is calc-alkaline with no Fe-enrichment. Compositional variations are consistent with fractional crystallization of olivine and plagioclase but approximately equal amount of each was removed. The apparent lack of augitic clinopyroxene from the separating assemblage means that fractional crystallization was at low pressure.

3. Group 5 glasses are intermediate between Group 1 and Group 2 glasses in major-element compositions. The liquid line of descent for the Group 5 glasses is also intermediate between those defined by Groups 1 and 2. We consider Group 1 samples to have formed from mantle containing a small amount of a sediment-like component; Group 2 samples from a mantle with a much larger amount of this component. The existence of Group 5 suggests that there is a continuum from MORB to calc-alkaline basalts.

The other groups of mafic glasses $(3,4,6)$ cannot be related directly to Groups 1,2 , or 5 by fractional crystallization. There was, therefore, a wide range of different primary liquids produced beneath the Taitao Ridge. Presumably this reflects the variable mantle sources tapped during interaction of ridge and trench.

4. Parental magmas for the Group 1 glasses appear to have been produced by melting processes similar to those for other N-type MORBs, typically involving polybaric fractional melting of ascending mantle at 1-3 GPa followed by mixing of the various fractions. The Group 1 glasses lie significantly off the MORB global array of Klein and Langmuir (1987) when plotted against mean axial depth, but lie on the $\mathrm{Fe}_{8.0}$ versus $\mathrm{Na}_{8.0}$ array, possibly suggesting that the present shallow depth is a tectonic anomaly rather than an original magmatic feature.

5. The silicic igneous rocks associated with the mafic glasses formed by remelting rocks derived from igneous rocks similar to Group 2 samples. The $\mathrm{Pb}$ isotopic ratios of the rhyolites and Group 2 basalts are identical. The rhyolites do, however, have higher ${ }^{87} \mathrm{Sr} /{ }^{86} \mathrm{Sr}$ than the Group 2 basalts. The elevation of ${ }^{87} \mathrm{Sr} /{ }^{86} \mathrm{Sr}$ is interpreted to reflect interaction of the source rocks with seawater-derived fluids. One rhyolite has ${ }^{143} \mathrm{Nd} /{ }^{144} \mathrm{Nd}$ identical to that of the Group 2 basalts but the other has much higher ${ }^{143} \mathrm{Nd} /{ }^{144} \mathrm{Nd}$.

Trace-element enrichments in the rhyolites are consistent with formation from Group 2 basalts. In particular, $\mathrm{Rb}$ and $\mathrm{K}$ are greatly enriched over LREE, and $\mathrm{Ba}$ and $\mathrm{Nb}$ are depleted just as in Group 2 basalts. The relative $\mathrm{Rb}$ contents suggest that the rhyolites formed by $10 \%$ melting of Group 2 samples. REE patterns of the rhyolites are consistent with $10 \%$ partial melting to leave a residue of plagioclase and hornblende. These minerals occur as phenocrysts in the silicic rocks and are interpreted as restite.

The Group 2 rocks collected in this study could not melt to rhyolites because they are essentially anhydrous and because they are olivine-normative. Gabbroic equivalents of such rocks are, therefore, quartz-free. Interaction of such rocks with hydrothermal fluids can produce plagioclase-hornblende-quartz-biotite rocks that melt to rhyolite liquids at $800^{\circ} \mathrm{C}$. The retention of the distinctive incompatibleelement pattern of the Group 2 basalts in the rhyolites shows that hydrothermal alteration was not intense. It may have been limited to addition of water (and radiogenic $\mathrm{Sr}$ ) to the Group 2 basalts.

\section{ACKNOWLEDGMENTS}

The microprobe lab at U.H. is supported by the State of Texas through the Texas Center for Superconductivity at the University of Houston. The isotope analyses were obtained through the generosity of Paul Fullagar and the Department of Geology at the University of North Carolina at Chapel Hill. JKM thanks Jonathan Miller, Brian Beard, and S. Goldberg for assistance in the lab.
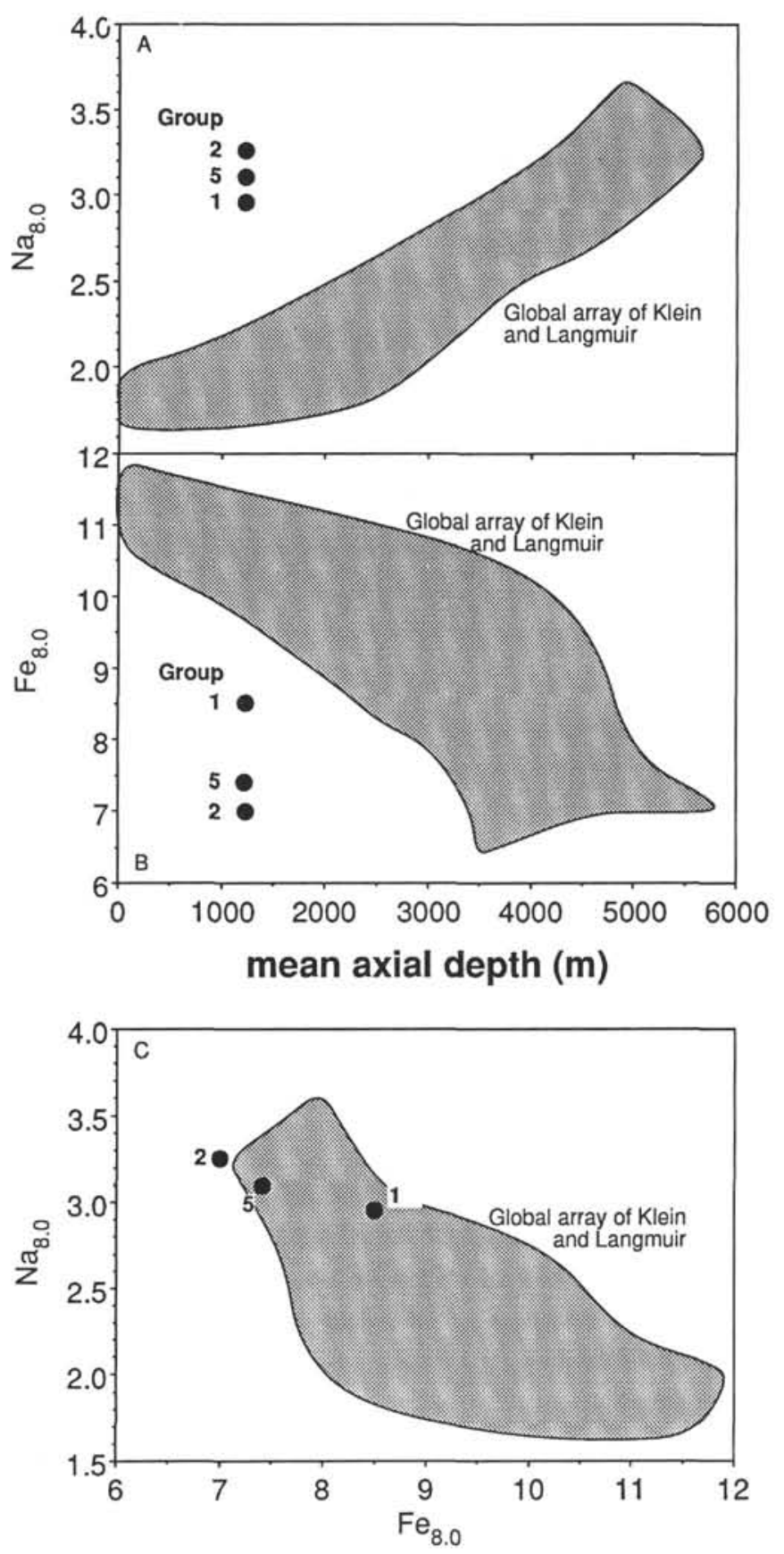

Figure 15. Plots of mean axial depth in meters against (A) $\mathrm{Na}_{8.0}$ and (B) $\mathrm{Fe}_{8.0}$ for Groups 1, 2, and 5 glasses from Suite 862. These are the contents of $\mathrm{Na}_{2} \mathrm{O}$ and $\mathrm{FeO}^{*}$ (in wt $\%$ ) at $\mathrm{MgO}=8 \%$ and were read directly off $\mathrm{MgO}-\mathrm{FeO}$ and $\mathrm{MgO}-\mathrm{Na}_{2} \mathrm{O}$ diagrams (Fig. 4). The global array is from Klein and Langmuir (1987). All three groups lie far off the global array. If Group 1 glasses were on the global arrays on Figure 14A when formed, the Taitao Ridge has been tectonically uplifted $2000-4000 \mathrm{~m}$. C. Plot of $\mathrm{Fe}_{8.0}$ against $\mathrm{Na}_{8.0}$ showing the position of glasses from Groups 1,2, and 5 compared with the global array of Klein and Langmuir (1987). The Group 1 basalt, interpreted here as an N-type MORB, lies on the global array, whereas the Group 2 basalt, interpreted here as a calc-alkaline basalt, lies at too low a value of $\mathrm{Fe}_{8.0}$. The Group 5 basalt is intermediate between these two. 


\section{REFERENCES}

Allen, J.C., and Boettcher, A.L., 1983. The stability of amphibole in andesite and basalt at high pressures. Am. Mineral., 68:307-314.

Allen, J.C., Boettcher, A.L., and Marland, G., 1975. Amphiboles in andesite and basalt, I. Stability as a function of P-T- $\mathrm{f}\left(\mathrm{O}_{2}\right)$. Am. Mineral., 60:10691085 .

Arth, J.G., 1976. Behaviour of trace elements during magmatic processes: a summary of theoretical models and their applications. J. Res. U.S. Geol. Surv., 4:41-47.

Beard, J.S., and Lofgren, G.E., 1991. Dehydration melting and water-saturated melting of basaltic and andesitic greenstones and amphibolites at 1,3 and 6.9 kb. J. Petrol., 32:365-401.

Behrmann, J.H., Lewis, S.D., Musgrave, R.J., et al., 1992. Proc. ODP, Init. Repts., 141: College Station, TX (Ocean Drilling Program).

Bence, A.E., Baylis, D.M., Bender, J.F., and Grove, T.L., 1979. Controls on the major and minor element chemistry of mid-ocean ridge basalts and glasses. In Talwani, M., Harrison, C.G., and Hayes D.E. (Eds.), Deep Sea Drilling Results in the Atlantic Ocean: Ocean Crust. Maurice Ewing Ser., Am. Geophys. Union, 2:331-341.

Bryan, W.B., 1979. Regional variation and petrogenesis of basalt glasses from the FAMOUS area, Mid-Atlantic Ridge. J. Petrol., 20:293-325.

Burnham, C.W., 1979. The importance of volatile constituents. In Yoder, H.S., Jr. (Ed.), The Evolution of the lgneous Rocks: Fiftieth Anniversary Perspectives: Princeton (Princeton Univ. Press), 439-482.

Fornari, D.J., Perfit, M.R., Malahoff, A., and Embley, R., 1983. Geochemical studies of abyssal lavas recovered by DSRV Alvin from Eastern Galapagas Rift, Inca Transform, and Ecuador Rift, 1. Major element variations in natural glasses and spatial distribution of lavas. J. Geophys. Res., $88: 10519-10529$.

Forsythe, R.D., Nelson, E.P., Carr, M.J., Kaeding, M.E., Herve, M., Mpodozis, C., Soffia, J.M., and Harambour, S., 1986. Pliocene near-trench magmatism in southern Chile: a possible manifestation of ridge collision. Geology, 14:23-27.

Forsythe, R.D., Olsson, R.K., Johnson, C., and Nelson, E.P., 1985. Stratigraphic and micropaleontologic observations from the Golfo de PenasTaitao Basin, southern Chile. Rev. Geol. Chile, 25/26:3-12.

Fujimaki, H., Tatsumoto, M., and Aoki, K., 1984. Partition coefficients of Hf, $\mathrm{Zr}$, and REE between phenocrysts and groundmasses. Proc. Lunar Planet. Sci. Conf., 14th (Part 2). J. Geophys. Res., 89 (Suppl.):B662-B672.

Grove, T.L., and Bryan, W.B., 1983. Fractionation of pyroxene-phyric MORB at low pressure: an experimental study. Contrib. Mineral. Petrol., 84:293309.

Grove, T.L., and Juster, T.C., 1989. Experimental investigations of low-Ca pyroxene and olivine-pyroxene-liquid equilibria at $\mathrm{I}$-atm in natural basaltic and andesitic liquids. Contrib. Mineral. Petrol.. 103:287-305.

Irvine, T.N., and Baragar, W.R.A., 1971. A guide to the chemical classification of the common volcanic rocks. Can. J. Earth Sci., 8:523-548,

Johnson, K.T.M., Dick, H.J.B., and Shimizu, N., 1990. Melting in the oceanic upper mantle: an ion microprobe study of diopsides in abyssal peridotites. J. Geophys. Res., 95:2661-2678.

Kaeding, M., Forsythe, R.D., and Nelson, E.P., 1990. Geochemistry of the Taitao ophiolite and near-trench intrusions from the Chile Margin Triple Junction. J. S. Am. Earth Sci., 3:161-177.
Kinzler, R.J., and Grove, T.L., 1992a. Primary magmas of mid-ocean ridge basalts, 1. Experiments and methods. J. Geophys. Res., 97:6885-6906. 1992b. Primary magmas of mid-ocean ridge basalts, 2. Applications. J. Geophys. Res., 97:6907-6926.

Klein, E.M., and Langmuir, C.H., 1987. Global correlations of ocean ridge basalt chemistry with axial depth and crustal thickness. J. Geophys. Res., 92:8089-8115.

McKenzie, D., 1985. The extraction of magma from the crust and mantle. Earth Planet. Sci. Lett., 74:81-91.

Michael, P.J., and Chase, R.L., 1987. The influence of primary magma composition, $\mathrm{H}_{2} \mathrm{O}$ and pressure on mid-ocean ridge basalt differentiation. Contrib. Mineral. Petrol., 96:245-263.

Miyashiro, A., 1974. Volcanic rock series in island arcs and active continental margins. Am. J. Sci., 274:321-355.

Mpodozis, M.C., Hervé, A.M., Nasi, P.C., Soffia, J.M., Forsythe, R.D., and Nelson, E.P., 1985. El magmatismo Plioceno de Peninsula Tres Montes y su relacion con la evolucion del Punto Triple de Chile Austral. Rev. Geol. Chile, 25/26:13-28.

Perfit, M.R., and Fornari, D.J., 1983. Geochemical studies of abyssal lavas recovered by DSRV Alvin from eastern Galapagos Rift, Inca Transform, and Ecuador Rift, 2. Phase chemistry and crystallization history. J. Geophys. Res., 88:10530-10550.

Salters, V.J.M., and Hart, S.R., 1989. The hafnium paradox and the role of garnet in the source of mid-ocean ridge basalts. Nature, 342:420-422.

Saunders, A.D., and Tarney, J., 1991. Back-arc basins. In Floyd, P.A. (Ed.), Oceanic Basalts: Glasgow (Blackie), 219-263.

Stern, C.R., Futa, K., and Muehlenbachs, K., 1984a. Isotope and trace element data for orogenic andesites from the austral Andes. In Harmon, R.S., and Barreiro, B.A. (Eds.), Andean Magmatism: Chemical and Isotopic Constraints: Nantwich (Shiva), 31-46.

Stern, C.R., Futa, K., Muehlenbachs, K., Dobbs, F.M., Munoz, J., Godoy, E., and Charrier, R., 1984b. Sr, Nd, $\mathrm{Pb}$ and $\mathrm{O}$ isotope composition of Late Cenozoic volcanics, northernmost SVZ (33-34 ${ }^{\circ}$ S). In Harmon, R.S., and Barreiro, B.A. (Eds.), Andean Magmatism: Chemical and Isotopic Constraints: Nantwich (Shiva), 96-105.

Sun, S.-S., and McDonough, W.F., 1989. Chemical and isotopic systematics of oceanic basalts: implications for mantle composition and processes. In Saunders, A.D., and Norry, M.J. (Eds.), Magmatism in the Ocean Basins. Geol. Soc. Spec. Publ. London, 42:313-345.

Taylor, S.R., and McLennan, S.M., 1985. The Continental Crust: Its Composition and Evolution: Oxford (Blackwell Scientific).

Unruh, D.M., and Tatsumoto, M., 1976. Lead isotopic composition and uranium, thorium, and lead concentrations in sediments and basalts from the Nazca plate. In Yeats, R.S., Hart, S.R., et al., Init. Repts. DSDP, 34: Washington (U. S. Govt. Printing Office), 341-347.

Abbreviations for names of organizations and publications in ODP reference lists follow the style given in Chemical Abstracts Service Source Index (published by American Chemical Society).

Date of initial receipt: 1 October 1993

Date of acceptance: 4 October 1994

Ms 141SR-030 